\title{
Evidence for the linked biogeochemical cycling of zinc, cobalt, and phosphorus in the western North Atlantic Ocean
}

\author{
R. Wisniewski Jakuba, ${ }^{1,2}$ J. W. Moffett, ${ }^{3,4}$ and S. T. Dyhrman ${ }^{5}$ \\ Received 1 October 2007; revised 23 August 2008; accepted 2 September 2008; published 22 November 2008.
}

[1] Many trace metals such as iron, copper, and manganese have lower concentrations in the surface waters of the North Pacific Ocean than in North Atlantic surface waters. However, cobalt and zinc concentrations in North Atlantic surface waters are often as low as those reported in the North Pacific. We studied the relationship between the distribution of cobalt, zinc, and phosphorus in surface waters of the western North Atlantic Ocean. Both metals show strong depletion in the southern Sargasso Sea, a region characterized by exceedingly low dissolved inorganic phosphorus (generally $<4 \mathrm{nmol} \mathrm{L}{ }^{-1}$ ) and measurable alkaline phosphatase activity. Alkaline phosphatase is a metalloenzyme (typically containing zinc) that cleaves phosphate monoesters and is a diagnostic indicator of phosphorus stress in phytoplankton. In contrast to the North Pacific Ocean, cobalt and zinc appear to be drawn down to their lowest values only when inorganic phosphorus is below $10 \mathrm{nmol} \mathrm{L}^{-1}$ in the North Atlantic Ocean. Lower levels of phosphorus in the Atlantic may contribute to these differences, possibly through an increased biological demand for zinc and cobalt associated with dissolved organic phosphorus acquisition. This hypothesis is consistent with results of a culture study where alkaline phosphatase activity decreased in the model coccolithophore Emiliania huxleyi upon zinc and cobalt limitation.

Citation: Jakuba, R. W., J. W. Moffett, and S. T. Dyhrman (2008), Evidence for the linked biogeochemical cycling of zinc, cobalt, and phosphorus in the western North Atlantic Ocean, Global Biogeochem. Cycles, 22, GB4012, doi:10.1029/2007GB003119.

\section{Introduction}

[2] Surface water concentrations of many trace metals are higher in the North Atlantic Ocean than in the North Pacific Ocean, reflecting riverine inputs and dust sources like the Saharan Desert and North America [e.g., Bruland and Franks, 1983; Arimoto et al., 2003]. However, two biologically active trace elements, cobalt $(\mathrm{Co})$ and zinc $(\mathrm{Zn})$, have surface water concentrations in the central gyre of the Sargasso Sea that are frequently as low as values reported in the central gyre of the North Pacific. The Sargasso Sea is extremely oligotrophic with inorganic nitrogen $(\mathrm{N})$ concentrations as low as $2.5 \mathrm{nmol} \mathrm{L^{-1 }}$ [Cavender-Bares et al., 2001] and with dissolved inorganic phosphorus (DIP) concentrations that can be less than $1 \mathrm{nmol} \mathrm{L}^{-1}[\mathrm{Wu}$ et al., 2000; Cavender-Bares et al., 2001]. Primary production in

\footnotetext{
${ }^{1}$ Massachusetts Institute of Technology, Woods Hole Oceanographic Institution Joint Program in Chemical Oceanography, Woods Hole, Massachusetts, USA.

${ }^{2}$ Now at Office of Research and Development, Environmental Protection Agency, Washington, DC, USA.

${ }^{3}$ Marine Chemistry and Geochemistry Department, Woods Hole Oceanographic Institution, Woods Hole, Massachusetts, USA.

${ }^{4}$ Now at Department of Biological Sciences, University of Southern California, Los Angeles, California, USA.

${ }^{5}$ Biology Department, Woods Hole Oceanographic Institution, Woods Hole, Massachusetts, USA.
}

Copyright 2008 by the American Geophysical Union. 0886-6236/08/2007GB003119\$12.00 the Sargasso Sea has been proposed to be limited by N [Graziano et al., 1996; Mills et al., 2004]; iron, through $\mathrm{N}_{2}$ fixation [Berman-Frank et al., 2001]; and phosphorus (P) [Wu et al., 2000; Sanudo-Wilhelmy et al., 2001; Ammerman et al., 2003; Lomas et al., 2004]. In the Sargasso Sea, the ratio of dissolved $\mathrm{N}$ to $\mathrm{P}$ in the water column can reach more than twice the classical Redfield value of 16N:1P (dissolved inorganic N:P of 40-50 [Cavender-Bares et al., 2001]). Field studies in the Sargasso Sea, using metrics of $P$ physiology such as P uptake, alkaline phosphatase activity, and $\mathrm{P}$ quotas, provide further evidence of P-limitation in this system [Cotner et al., 1997; Wu et al., 2000; SanudoWilhelmy et al., 2001; Dyhrman et al., 2002; Ammerman et al., 2003; Mather et al., 2008]. A recent study suggests that $\mathrm{N}$ may be the proximal limiting nutrient for some organisms and for carbon fixation in the Sargasso Sea but that Synechococcus, the dominant phytoplankter, and the overall autotrophic community yield appears to be colimited by $\mathrm{N}$ and $\mathrm{P}$ [Moore et al., 2008].

[3] When DIP is depleted, most phytoplankton induce the metalloenzyme alkaline phosphatase (AP), which cleaves phosphomonester bonds, facilitating the acquisition of phosphorus from the dissolved organic phosphorus pool [Cembella et al., 1984, and references therein]. Thus under low P conditions, dissolved organic phosphorus (DOP) may become a critical P source [Mather et al., 2008], especially considering that in many oligotrophic systems, DOP accounts for the majority of the total dissolved $\mathrm{P}$ pool in 
surface waters $(94-99 \%$ in the North Atlantic [Wu et al., 2000; Cavender-Bares et al., 2001]). Using in situ DOP concentrations and AP activities, Mather et al. [2008] estimate that the DOP pool supports $20 \%$ of primary production in the North Atlantic subtropical gyre, though this estimate would be substantially higher (up to $90 \%$ ) if geochemical estimates of new production are used instead of carbon fixation rates. At the Bermuda Atlantic Timeseries Study (BATS) site, AP activity is generally detectable year-round in the upper $100 \mathrm{~m}$ [Ammerman et al., 2003]. AP typically contains $\mathrm{Zn}$ (for instance in Escherichia coli [Plocke et al., 1962]), though a Co-containing AP was found in bacteria isolated from a hot spring [Gong et al., 2005]. Phytoplankton in low P regimes may have elevated requirements for $\mathrm{Zn}$ and $\mathrm{Co}$, contributing to the low $\mathrm{Zn}$ and Co concentrations observed in the oligotrophic Sargasso Sea. Additional $\mathrm{Zn}$ - or Co-containing metalloenzyme systems are involved in the utilization of other forms of DOP, such as phosphonates [Kulakova et al., 2003], which may also elevate the requirements of phytoplankton for Co and $\mathrm{Zn}$.

[4] Zinc and Co concentrations in Sargasso Sea surface waters are among the lowest in the world [Bruland and Franks, 1983; Saito and Moffett, 2002]. Both Co and Zn are highly complexed by organic ligands in the North Atlantic, which further decreases their free ion concentrations [Ellwood and van den Berg, 2000, 2001; Saito and Moffett, 2001; Jakuba et al., 2008]. The free $\mathrm{Zn}^{2+}$ ion concentrations found in the Sargasso Sea are low enough to restrict growth of some phytoplankton species in culture [Brand et al., 1983]. These low values reflect biological utilization, including AP synthesis, and they may also restrict metalloenzyme activity under some conditions. Low-density batch cultures of the coccolithophore Emiliania huxleyi grown under low P conditions had lower AP activity when grown at low dissolved inorganic $\mathrm{Zn}$ concentrations $\left(0.4 \mathrm{pmol} \mathrm{L}^{-1} \mathrm{Zn}\right)$ than when grown at high $\mathrm{Zn}\left(15 \mathrm{pmol} \mathrm{L}^{-1} \mathrm{Zn}\right.$ [Shaked et al., 2006]). In an incubation in the Bering Sea, increased AP activity was observed in bottles amended with $\mathrm{Zn}$ over that in control and in iron addition bottles [Shaked et al., 2006]. Extrapolating their results to field concentrations of $\mathrm{P}$ and $\mathrm{Zn}$, the authors do not predict $\mathrm{Zn} / \mathrm{P}$ colimitation to be a widespread phenomenon; however, they suggest it may occur in the Sargasso Sea [Shaked et al., 2006] where both P and Zn are very low. Co-limitation by $\mathrm{Co}$ and $\mathrm{P}$ has not been examined in as great detail as the relationship between $\mathrm{Zn}$ and $\mathrm{P}$, which is largely due to the focus on Zn-containing APs. However, Co is also very low in the Sargasso Sea and can be the metal center in some APs [Gong et al., 2005].

[5] Culture studies have revealed different metal requirements amongst phytoplankton taxa. For instance, the diatom Thalassiosira weissflogii has a $\mathrm{Zn}$ requirement that can be partially met with Co, whilst the coccolithophore E. huxleyi has a Co requirement that can be partially met with $\mathrm{Zn}$ [Sunda and Huntsman, 1995; Xu et al., 2007]. The picocyanobacteria Synechococcus and Prochlorococcus have absolute Co requirements that cannot be met with $\mathrm{Zn}$ [Sunda and Huntsman, 1995; Saito et al., 2002]. The relative proportion of $\mathrm{Zn}$ to Co may therefore favor the growth of certain species over others [Sunda and Huntsman,
1995]. This has important implications for the global carbon cycle since the carbon:carbonate rain ratio (a parameter that influences the effectiveness of the biological pump in removing carbon dioxide from the atmosphere [Archer and Maier-Reimer, 1994]) is largely controlled by the dominance of diatoms versus coccolithophores.

[6] This study examines the relationships between $\mathrm{P}, \mathrm{Zn}$, and $\mathrm{Co}$ and their effect on phytoplankton along a nearsurface transect in the western North Atlantic Ocean, encompassing waters from 20 to $40^{\circ} \mathrm{N}$. In the northern Sargasso Sea (north of $\sim 31^{\circ}$ ), seasonal mixing in the winter results in the injection of nutrients into the euphotic zone leading to spring phytoplankton blooms, followed by increasing stratification and nutrient depletion in the summer [Michaels and Knap, 1996]. In the southern Sargasso Sea (south of $\sim 31^{\circ}$ ), the upper water column remains stratified and oligotrophic throughout the year [Michaels and Knap, 1996]. Thus the transect provided an opportunity to study P, $\mathrm{Zn}$, and Co across gradients in nutrient concentrations and phytoplankton community structure. Field data are supported by culture work using the coccolithophore E. huxleyi, an important species in the transitional region between the north and south Sargasso regimes [Cavender-Bares et al., 2001; Haidar and Thierstein, 2001].

\section{Methods}

\subsection{Sample Collection}

[7] Samples were collected aboard the R/V Oceanus between 20 March 2004 and 9 April 2004 (Figure 1) from approximately $10 \mathrm{~m}$ depth using either $10 \mathrm{~L}$ teflon-coated Go-Flos (General Oceanics) or an air-driven teflon pump (Saint-Gobain Performance Plastics) on a kevlar hydrowire.

\subsection{Chlorophyll}

[8] At each station, seawater was collected and passed through a GF/F filter. Filters were extracted in $90 \%$ acetone overnight at $-20^{\circ} \mathrm{C}$ and analyzed using a handheld Aquafluor fluorometer (Turner Designs). Chlorophyll $a$ (Chl $a$ ) concentrations were calculated following the publicly available BATS protocol (http://bats.bios.edu/batsmethods.html) based on Herbland et al. [1985, and references therein].

\subsection{Phosphorus}

[9] Samples were filtered $(0.4 \mu \mathrm{m}$ acid-washed polycarbonate filter) through an acid-cleaned $(10 \%$ J.T. Baker Instra-Analyzed $\mathrm{HCl})$ filter tower into acid-cleaned $(10 \%$ J.T. Baker Instra-Analyzed $\mathrm{HCl}$ ) low-density polyethylene bottles and were immediately frozen and stored at $-20^{\circ} \mathrm{C}$. For the majority of the samples, DIP was measured based upon the MAGIC method developed by Karl and Tien [1992] as modified by Rimmelin and Moutin [2005]. Analysis of the few remaining samples is described elsewhere [Dyhrman et al., 2006]. Sample aliquots of $50 \mathrm{~mL}$ were placed in acid-washed polypropylene centrifuge tubes and pre-concentrated by magnesium hydroxide precipitation. Sodium hydroxide (350 $\mu \mathrm{L}$ of $1 \mathrm{~mol} \mathrm{~L}^{-1}$ solution, Fluka) was added to the tubes and the tubes inverted immediately to mix. After $5 \mathrm{~min}$, the tubes were inverted a second time, and after an additional $5 \mathrm{~min}$, the tubes were centrifuged at 


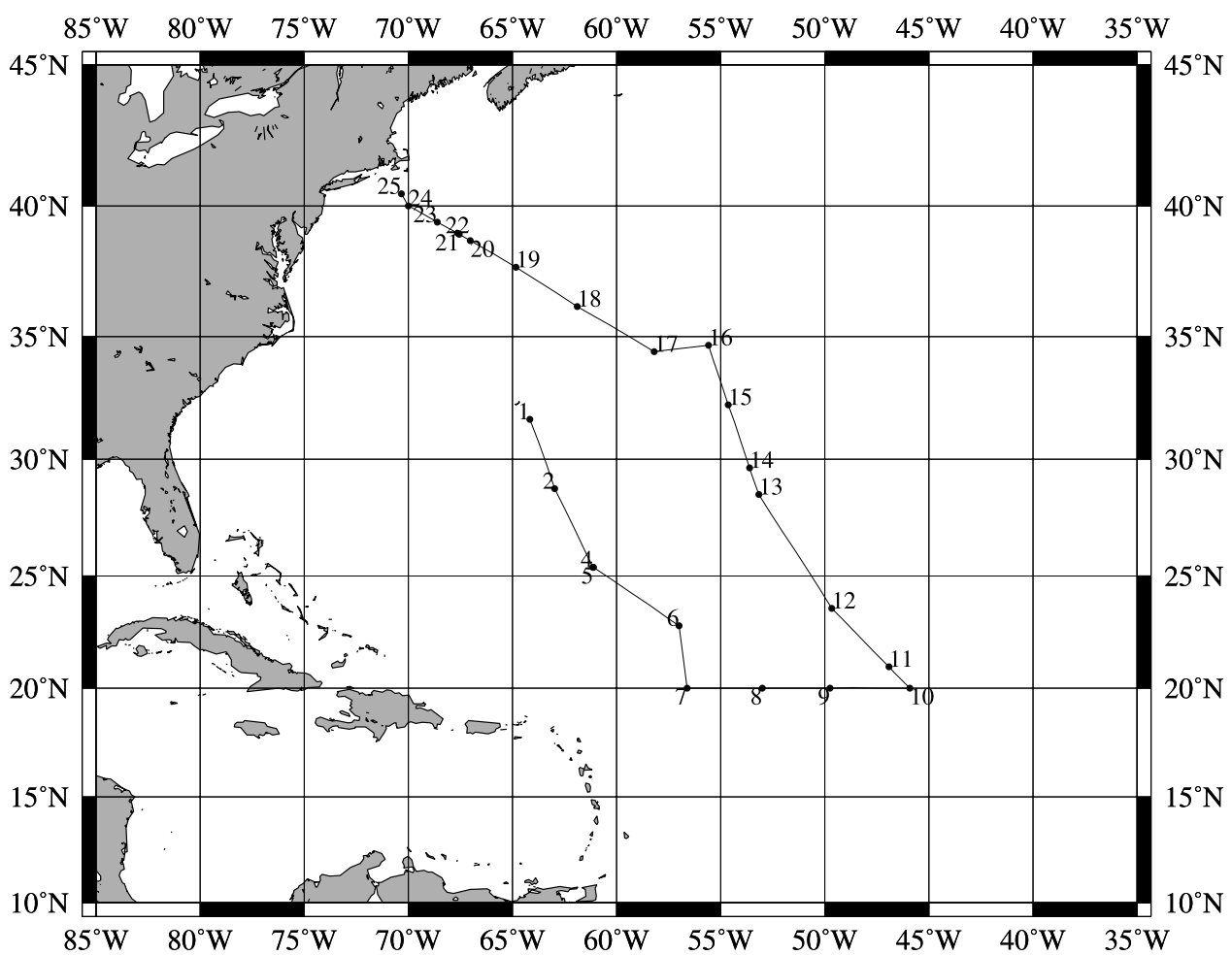

Figure 1. Map of the cruise track in the western North Atlantic Ocean that was sampled aboard the R/V Oceanus during March-April 2004.

$3000 \mathrm{rpm}(1811 \times g)$ for $10 \mathrm{~min}$. The supernatant was carefully removed using a pipette. The precipitate was dissolved in 1-2 $\mathrm{mL}$ of $0.25 \mathrm{~mol} \mathrm{~L}^{-1}$ hydrochloric acid (Seastar $\mathrm{HCl}$ ) and subsequently analyzed using the molybdate blue method [Murphy and Riley, 1962] and corrected for arsenic interference as per Johnson [1971]. Standards were prepared by adding $0-200 \mathrm{nmol} \mathrm{L} \mathrm{NaH}_{2} \mathrm{PO}_{4}$ to $50 \mathrm{~mL}$ aliquots of Sargasso seawater that were treated identically to samples. Synthetic blanks were prepared as in Rimmelin and Moutin [2005] and consisted of $1.05 \mathrm{~mL}$ of $1 \mathrm{~mol} \mathrm{~L}^{-1}$ sodium hydroxide solution, $4.2 \mathrm{~mL}$ of $0.25 \mathrm{~mol}$ $\mathrm{L}^{-1} \mathrm{HCl}, 600 \mathrm{~L}$ reducing agent, $150 \mu \mathrm{L}$ Milli-Q, $120 \mu \mathrm{L}$ $0.3 \mathrm{~mol} \mathrm{~L}^{-1}$ ascorbic acid, and $480 \mu \mathrm{L}$ molybdic reagent. The $\mathrm{P}$ concentrations measured by this method are termed soluble reactive phosphorus (SRP) since hydrolysis of some DOP compounds may occur under the acidic reaction conditions. The blank value was subtracted from the measured sample concentration (average blank value was $0.2 \mathrm{nmol} \mathrm{L}^{-1}$ ). The average detection limit (calculated as three times the standard deviation of the blank) was $1.2 \mathrm{nmol} \mathrm{L}^{-1}$. In cases where the measured SRP value fell below the detection limit $(n=2)$, values are plotted as the detection limit or listed as < daily detection limit. For stations 21-25, where the SRP values were greater than $300 \mathrm{nmol} \mathrm{L}^{-1}$, samples were analyzed without the MAGIC pre-concentration. For total dissolved phosphorus (TDP) analysis, $15 \mathrm{~mL}$ of sample was placed in a quartz test tube and $40 \mu \mathrm{L}$ of hydrogen peroxide was added. Samples were then UV digested [Armstrong et al., 1966] for twelve hours followed by analysis with the molybdate blue method [Murphy and Riley, 1962]. DOP concentration was defined as the difference between the TDP and the SRP measurements.

\subsection{Alkaline Phosphatase Activity}

[10] AP activity was assayed using the fluorogenic substrate 6,8-diuoro-4-methylumbelliferyl phosphate (diFMUP, Molecular Probes), after Perry [1972] as modified by Ruttenberg and Dyhrman [2005]. For each sample, $500 \mathrm{~mL}$ of seawater was passed through a $0.4 \mu \mathrm{m}$ acid-washed polycarbonate filter. The filter was placed in a Petri dish and stored frozen for approximately 24 hours. At the time of analysis, $2 \mathrm{~mL}$ of autoclaved phosphate-free artificial seawater [Lyman and Fleming, 1940] was added to each Petri dish. By using a phosphate-free buffer in the assay, we avoided possible substrate/product inhibition of the AP activity, and thereby measured maximal potential activity associated with particles. Petri dishes were incubated at room temperature in the dark and agitated on a shaker table for 10 minutes, after which $10 \mu \mathrm{M}$ of diFMU-P substrate was added. Fluorescence of the sample was measured by pipetting $200 \mu \mathrm{L}$ from the filter solution into a well-plate which was inserted into a Cyto-fluor fluorescence reader (Applied Biosystems). A fresh $200 \mu \mathrm{L}$ sample aliquot was pipetted into the well-plate and fluorescence measured every 5-10 min for 5 time points. Blanks were prepared by adding diFMU-P substrate to filters without cell concentrates; the fluorescence of these blank filters was subtracted from the sample fluorescence. For the first three stations, AP activity was also assayed on $<0.4 \mu \mathrm{m}$ filtered water samples to determine whether or not there was a 
significant dissolved component to the total AP activity. For these assays, $1 \mathrm{~mL}$ filtered water was pipetted into a Petri dish and $10 \mu \mathrm{M}$ diFMU-P substrate was added. Fluorescence of the sample over time was measured as above. All AP assays were performed with saturating levels of substrate $\left(10 \mu \mathrm{mol} \mathrm{L}{ }^{-1}\right)$ in phosphate free buffer. Thus the AP activities reported are maximum or potential activities.

[11] Alkaline phosphatase activity is often reported normalized to biomass [e.g., Li et al., 1998; Shaked et al., 2006]. This is informative as it provides a way to distinguish between a low level of activity expressed by a large biomass of cells and a high level of activity on a per cell mass basis. Chl $a$ was used as a biomass proxy for AP activity normalization in this study, which requires certain caveats. First, Chl $a$ is a bulk parameter encompassing the entire phytoplankton community, yet the presence of AP activity within the community can be quite varied over small spatial scales [Dyhrman et al., 2002; Lomas et al., 2004], with some species having AP activity while others do not. Additionally, AP activity can be present in organisms that do not contain Chl $a$. Finally, although AP activity is typically associated with the cell surface, AP activity can be detected in the dissolved fraction [e.g., Vidal et al., 2003]. Single-cell assays of enzyme activity are valuable for elucidating some of these complexities [Dyhrman et al., 2002]. However, they do not provide a quantitative measure of activity, and at this point, cannot be uniformly applied to all taxa; there has been difficulty labeling the picocyanobacteria, which predominate in much of the Sargasso Sea. AP activity in this study was determined in the $>0.4 \mu \mathrm{m}$ fraction, which includes picocyanobacteria. This approach has been applied previously in other systems [Ruttenberg and Dyhrman, 2005; Dyhrman and Ruttenberg, 2006]. Measuring AP activity in this manner attempts to eliminate AP activity due to the dissolved fraction, thus strengthening the rationale for normalization to Chl $a$. Throughout this manuscript, results will be presented both with normalization to Chl $a$ and on a per volume basis, but it is important to bear in mind that all reported activities were measured on cell concentrates.

\subsection{Zinc}

[12] All samples were collected using trace metal clean techniques. Samples were drawn directly from the Go-Flo bottles by teflon tubing through acid-cleaned $0.4 \mu \mathrm{m}$, $142 \mathrm{~mm}$ diameter, polycarbonate filters held in a polycarbonate filter sandwiches (Geotech Environmental Equipment, Inc.) into rigorously acid-cleaned low-density polyethylene bottles (including sequential soaks in warm Citranox detergent, $6 \mathrm{~N} \mathrm{HCl}, 5 \% \mathrm{HNO}_{3}$, and $\mathrm{pH} 2 \mathrm{HCl}$ ). After filtration, samples were acidified to approximately $\mathrm{pH} 2$ by the addition of $2 \mathrm{~mL}$ concentrated $\mathrm{HCl}$ (Seastar) per liter of seawater. Total dissolved $\mathrm{Zn}$ concentration was measured using isotope dilution and magnesium hydroxide pre-concentration followed by analysis using inductively coupled plasma mass spectrometry (ICP-MS) after $W u$ and Boyle [1998] and Saito and Schneider [2006]. The $15 \mathrm{~mL}$ polypropylene centrifuge tubes (Globe Scientific Inc.) were cleaned by soaking in $2 \mathrm{~N} \mathrm{HCl}$ at $60^{\circ} \mathrm{C}$ for 48 hours, followed by rinsing 5 times with trace-metal grade $\mathrm{pH}$ $2 \mathrm{HCl}$ (J.T. Baker instra-analyzed) and once with ultra-pure pH $2 \mathrm{HCl}$ (Seastar). Finally, tubes were filled to a positive meniscus with ultra-pure $\mathrm{pH} 2 \mathrm{HCl}$ (Seastar) and capped until use. At the time of analysis, tubes were rinsed once with sample and then filled with $\sim 13.5 \mathrm{~mL}$ of sample (exact volume determined gravimetrically). Samples were then spiked with a ${ }^{66} \mathrm{Zn}$ spike $\left(98.9 \%\right.$ as ${ }^{66} \mathrm{Zn}$, Cambridge Isotope Laboratories, Inc.) and allowed to equilibrate overnight. The following day, $125 \mu \mathrm{L}$ of $11 \mathrm{~mol} \mathrm{~L}^{-1}$ ammonium hydroxide (Seastar) was added to each tube. After $90 \mathrm{sec}$, the tube was inverted and after an additional $90 \mathrm{sec}$, tubes were centrifuged for $3 \mathrm{~min}$ at $3000 \times g(3861 \mathrm{rpm})$ using a swinging bucket centrifuge (Eppendorf). The majority of the supernatant was decanted carefully and then tubes were respun for $3 \mathrm{~min}$ to form a firm pellet and the remaining supernatant was shaken out. Pellets were stored dry until the day of analysis (no longer than a few days). Pellets were dissolved on the day of ICP-MS analysis using $0.5-1.5 \mathrm{~mL}$ of $5 \%$ nitric acid (Seastar). ICP-MS measurements were made using a Finnigan ELEMENT2 in medium resolution mode, which was sufficient to resolve ${ }^{64} \mathrm{Zn}$ from the potential interference peak due to the $\mathrm{MgAr}^{+}$ion. The reported values have had the procedural blank subtracted. To measure the procedural blank, $1 \mathrm{~mL}$ of low $\mathrm{Zn}$ surface seawater was treated as the samples but calculations were performed as though it was a $13.5 \mathrm{~mL}$ sample ( $\mathrm{Zn}$ contribution from the $1 \mathrm{~mL}$ is considered negligible). The average blank value was $0.14 \mathrm{nmol} \mathrm{L}^{-1}$ and the average detection limit was $0.08 \mathrm{nmol} \mathrm{L}^{-1}$.

\subsection{Cobalt}

[13] The same samples were used for both $\mathrm{Zn}$ and Co analyses (see above for collection procedure). The total dissolved Co concentrations were measured using Cathodic Stripping Voltammetry (CSV) following the method of Saito and Moffett [2001]. Reagents included N-(2-Hydroxyethyl)piperazine- $N$-(3-propanesulfonic acid) (EPPS, Sigma) buffer, sodium nitrite (Fluka Puriss), and dimethylglyoxime (DMG, Aldrich). Both the EPPS and nitrite reagents were treated with Chelex-100 to remove any contaminating metals. DMG was purified as per Saito and Moffett [2001].

[14] Acidified samples were poured into quartz tubes that were cleaned by soaking overnight in $10 \% \mathrm{HCl}$ (J.T. Baker Instra-Analyzed) and rinsed several times with $\mathrm{pH} 2 \mathrm{HCl}$ (J.T. Baker Instra-Analyzed). Samples were then UV-irradiated for 1 hour using a 500 Watt high-pressure mercury lamp (Metrohm) and pipetted from the quartz tubes into a teflon cell cup of a Metrohm 663 VA Stand in hanging mercury drop mode. The $\mathrm{pH}$ was adjusted to between 8.0 and 8.5 using ammonium hydroxide (Seastar). EPPS buffer ( $\mathrm{pH}$ adjusted to 8.1) was added to a concentration $2.5 \mathrm{mmol}$ $\mathrm{L}^{-1}$; DMG was added to a concentration of $0.3 \mathrm{mmol} \mathrm{L}^{-1}$; and sodium nitrite was added to a concentration of $225 \mathrm{mmol} \mathrm{L}^{-1}$. The sample was purged with ultra-highpurity nitrogen gas for $200 \mathrm{sec}$. A voltage of $-0.6 \mathrm{~V}$ was applied to the voltammetric cell for $90 \mathrm{sec}$ followed by a $10 \mathrm{sec}$ equilibration period before the potential was ramped from -0.6 to $-1.4 \mathrm{~V}$. The scan was performed using the linear sweep wave form at a speed of $7.01 \mathrm{~V} \mathrm{sec}^{-1}$ with a step 
Table 1. Free Ion Concentrations of $\mathrm{Co}$ and $\mathrm{Zn}$ in the Culture Media for Each Metal Treatment are Presented as Log of the Molar Concentration $^{\mathrm{a}}$

\begin{tabular}{lccc}
\hline \multicolumn{1}{c}{ Treatment } & Abbreviation & $\log \left[\mathrm{Zn}^{2+}\right]$ & $\log \left[\mathrm{Co}^{2+}\right]$ \\
\hline Replete $\mathrm{Zn}$ and Co & $+\mathrm{Zn} /+\mathrm{Co}$ & -10.6 & -10.1 \\
No Zn added, low Co & $-\mathrm{Zn}$ & -13.0 & -12.3 \\
No Co added, low $\mathrm{Zn}$ & $-\mathrm{Co}$ & -12.3 & -14.8 \\
No Zn added, no Co added & $-\mathrm{Zn} /-\mathrm{Co}$ & -13.0 & -14.8 \\
\hline
\end{tabular}

${ }^{a}$ Values were calculated using the program Visual MINTEQ based on both the background levels of $\mathrm{Co}$ and $\mathrm{Zn}$ in the seawater base and on the metals added to the media.

potential of $0.01 \mathrm{~V}$. The zero addition scan was repeated 3 times, followed by one scan each of 3 successive $20 \mathrm{pmol} \mathrm{L}^{-1}$ additions of Co. The reported values have had the procedural/ reagent blanks subtracted. Blanks were prepared by Chelexing UV-irradiated seawater and then UV-irradiating it a second time. The average blank was $4.6 \mathrm{pmol} \mathrm{\textrm {L } ^ { - 1 }}$ and the detection limit was $2.7 \mathrm{pmol} \mathrm{L}^{-1}$.

\subsection{Culture Study}

[15] Culture media were prepared using trace metal clean and sterile techniques in a class 100 clean room. The base of the medium was Sargasso seawater, collected from a teflon pump at St. 12. Seawater was filtered through a $0.4 \mu \mathrm{m}$ polycarbonate filter and microwave sterilized. This seawater base was amended with Chelexed and filter-sterilized stocks of nitrate and vitamins up to f/2 levels [Guillard, 1975; Guillard and Ryther, 1962]. A modified f/2 trace metal mix was used; trace metals were added with EDTA to final concentrations of $100 \mu \mathrm{mol} \mathrm{L}^{-1}$ EDTA (SigmaUltra, disodium salt), $40 \mathrm{nmol} \mathrm{L}^{-1}$ copper, $500 \mathrm{nmol} \mathrm{L}^{-1} \mathrm{Fe}, 50 \mathrm{nmol} \mathrm{L}^{-1}$ manganese, $52 \mathrm{nmol} \mathrm{L}^{-1}$ molybdenum, and varying levels of $\mathrm{Co}$ and $\mathrm{Zn}$. The free ion concentrations for the metals of each treatment were calculated using the computer program Visual MINTEQ. There were 4 metal conditions (replete $\mathrm{Zn}$ and $\mathrm{Co}$; no $\mathrm{Zn}$ added, low Co; no Co added, low $\mathrm{Zn}$; no $\mathrm{Zn}$ added, no Co added; for abbreviations and free metal ion concentrations, see Table 1) and two P conditions (low P, high $\mathrm{P}$ ) for a total of 8 treatments. For the high-P treatments, $36 \mu \mathrm{mol} \mathrm{L}{ }^{-1}$ of Chelexed $\mathrm{Na}_{2} \mathrm{HPO}_{4}$ was added to the media; $1 \mu \mathrm{mol} \mathrm{L}{ }^{-1}$ of Chelexed $\mathrm{Na}_{2} \mathrm{HPO}_{4}$ was added for the low-P treatments.

[16] An axenic culture of E. huxleyi (CCMP 374) was obtained from the Provasoli-Guillard Center for Culture of Marine Phytoplankton. Before beginning the experiment, E. huxleyi was transferred to low-metal media to dilute any carryover contamination. All cultures were grown in $30 \mathrm{~mL}$ acid-washed polycarbonate tubes, in triplicate. Growth of the cultures was monitored daily by measuring in vivo Chl $a$ fluorescence on a Turner Designs model 10-AU Fluorometer (Turner Designs) and by performing cell counts with a hemocytometer on days where AP activity was measured.

[17] For the low-P treatments, AP activity was measured daily for 4 days once growth of cultures had entered the logstationary transition (beginning day 7 for the Replete, day 8 for the $-\mathrm{Zn}$, and day 12 for both the $-\mathrm{Co}$ and $-\mathrm{Zn} /-\mathrm{Co}$ treatments), known from prior work to encompass peak AP activity [Dyhrman and Palenik, 2003]. In a previous experiment with E. huxleyi, there was no activity detectable at the
$\mathrm{P}$ concentration used in the high-P treatment. As such, AP assays were only performed on one day for the high-P treatments ( 3 rd day of stationary phase for $+\mathrm{Zn} /+\mathrm{Co},-\mathrm{Zn}$, $-\mathrm{Zn} /-\mathrm{Co}$; 1 st day of stationary phase for $-\mathrm{Co})$. For all AP assays, $650 \mu \mathrm{l}$ of culture was removed from each tube, using sterile techniques and acid-washed pipette tips. This aliquot was split: $500 \mu \mathrm{L}$ was placed in an acid-washed well plate for the enzyme assay and the remaining $150 \mu \mathrm{L}$ was placed in an epitube and preserved with $\sim 2 \%$ Lugol's reagent for cell counts. $20 \mu \mathrm{mol} \mathrm{L}{ }^{-1}$ diFMU-P substrate was added to each well using sterile acid-washed tips. The plate was then inserted into a Fluorstar fluorescence reader (BMG Labtech). Fluorescence was measured every 30$180 \mathrm{sec}$ for up to $45 \mathrm{~min}$. Fluorescence in a no-cells control of autoclaved phosphate-free artificial seawater [Lyman and Fleming, 1940] plus diFMU-P substrate was subtracted from culture samples. To obtain a rate measurement, a line was fitted to at least 6 points with an $R^{2}$ of 0.9 or better. If no line could be fit using these conditions, the activity was deemed undetectable. Samples for SRP analysis were collected at the end of the experiment (last day of AP analysis). The culture tubes were centrifuged at $8000 \mathrm{rpm}$ for $10 \mathrm{~min}$ to concentrate the cells into a pellet. The supernatant was transferred by pipette into acid-clean tubes and frozen at $-20^{\circ} \mathrm{C}$ until analysis. On duplicate supernatants, SRP was measured using the standard molybdate blue method without preconcentration [Murphy and Riley, 1962].

\section{Results}

\subsection{Chlorophyll}

[18] Chl a concentrations were generally low (0.02$0.06 \mu \mathrm{g} \mathrm{L}^{-1}$, Figure 2A, Table 2) in the southern half of the transect (south of $31^{\circ} \mathrm{N}$ ) and much higher $\left(0.10-1.90 \mu \mathrm{g} \mathrm{L}^{-1}\right)$ in the northern half (north of $32^{\circ} \mathrm{N}$ ). Concentrations were similar in magnitude and spatial distribution to previous studies in the Sargasso Sea [Siegel et al., 1990; Cavender-Bares et al., 2001].

\subsection{Phosphorus}

[19] SRP concentrations ranged from sub-nanomolar values (reported as below detection limit) in the southern portion of the transect to $585 \mathrm{nmol} \mathrm{L}^{-1}$ near the continental shelf (Table 2, Figure 2B). In the southern permanently stratified region, SRP was generally less than $4 \mathrm{nmol} \mathrm{L}^{-1}$ and increased significantly only north of $35^{\circ} \mathrm{N}$. DOP ranged from 51 to $308 \mathrm{nmol} \mathrm{L}^{-1}$ with an average value of $133 \mathrm{nmol}$ $\mathrm{L}^{-1}$ (Table 2, Figure 2C). The SRP and DOP concentrations agree with past studies in this region using the same methodology [Wu et al., 2000; Cavender-Bares et al., 2001]. At 17 out of 25 total stations, the SRP concentration was below the detection limit $\left(30-50 \mathrm{nmol} \mathrm{L}^{-1}\right)$ of the standard molybdate blue method [Murphy and Riley, 1962]. Extreme care was taken in analysis of SRP samples, and the high grades of reagents used were essential for obtaining the low blanks required for the detection of nanomolar SRP.

[20] As with SRP, high DOP values were observed at the northern-most stations. However unlike SRP, the lowest DOP concentrations were observed in the middle of the transect $\left(28-38^{\circ} \mathrm{N}\right)$ with intermediate concentrations south of $28^{\circ} \mathrm{N}$. South of $35^{\circ} \mathrm{N}$, DOP accounted for $96 \%$ on 

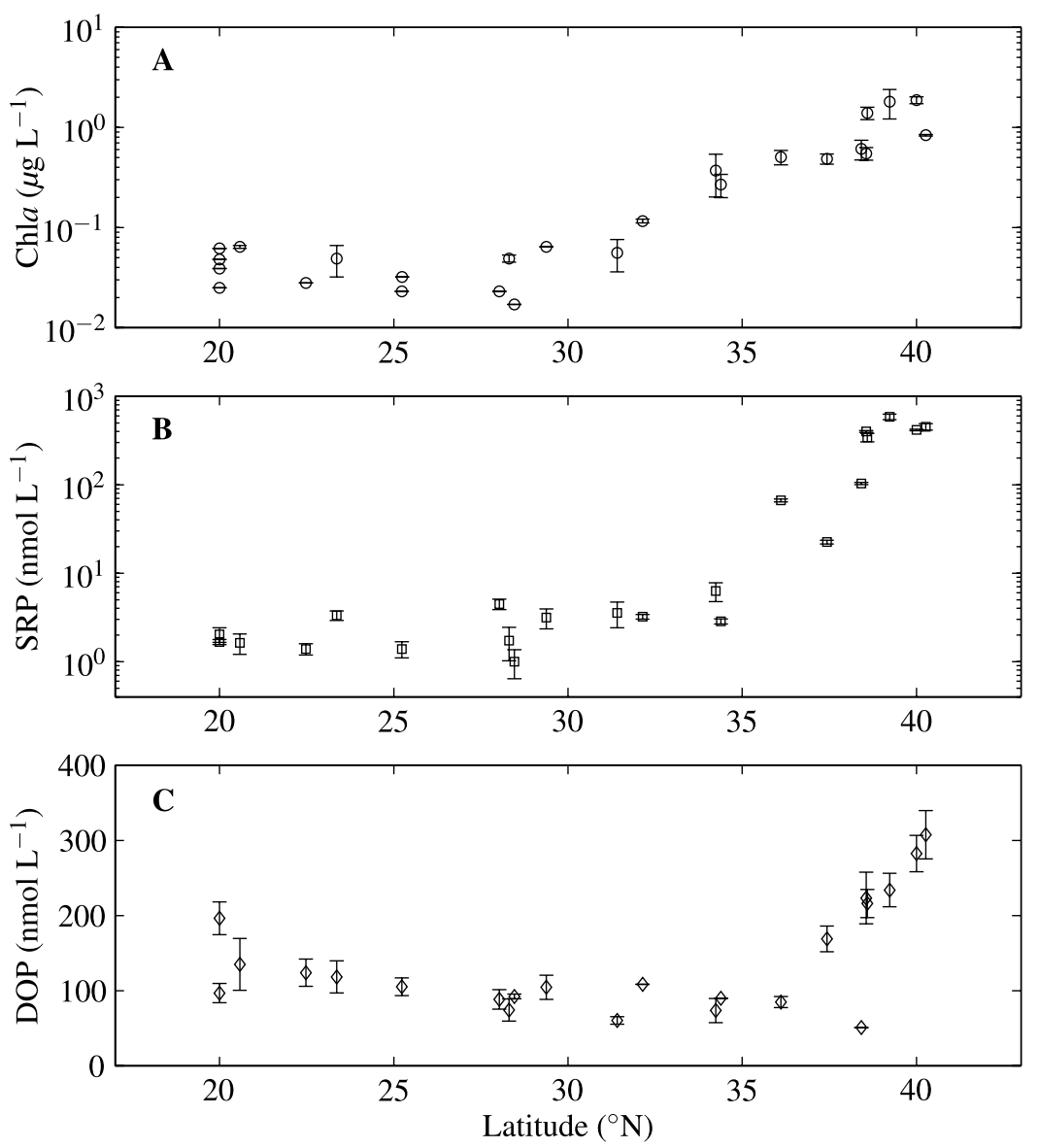

Figure 2. Concentrations of (A) Chlorophyll $a$, (B) soluble reactive phosphorus, and (C) dissolved organic phosphorus at approximately $10 \mathrm{~m}$ along the transect. Error bars represent the standard deviation between duplicate filters for $\mathrm{Chl} a$ and triplicate analyses for SRP and DOP. Note the $\log$ scale on the $y$-axis for Figures $2 \mathrm{~A}$ and $2 \mathrm{~B}$.

average of the total dissolved $\mathrm{P}$ pool in near-surface waters. North of $35^{\circ} \mathrm{N}$, where SRP concentrations were higher $\left(>65 \mathrm{nmol} \mathrm{L}^{-1}\right)$, SRP was the dominant fraction in the near-surface, and DOP accounted for less than half of the total dissolved $\mathrm{P}$ pool ( $45 \%$ on average).

\subsection{Alkaline Phosphatase Activity}

[21] Alkaline phosphatase activities are presented normalized to Chl $a$ concentrations (Figure 3A) and on a per volume basis (Figure 3B). AP activity was detected at all stations along the transect where measured (no data obtained for stations 24, 25). Chl $a$-normalized activities ranged from 3 to $105 \mathrm{nmol} \mathrm{P} \mathrm{hr}^{-1}(\mu \mathrm{g} \mathrm{Chl} a)^{-1}$, while AP activities on a per volume basis were between 1.2 and $13.9 \mathrm{nmol} \mathrm{P} \mathrm{hr}{ }^{-1} \mathrm{~L}^{-1}$. The measured AP activity in this study agrees well with previous measurements of AP activity at the BATS site, which were 1-10 nmol P hr ${ }^{-1} \mathrm{~L}^{-1}$ in March-April 19961998 [Ammerman et al., 2003]. The trend in AP activity along the transect differs depending on whether or not it is normalized to $\mathrm{Chl} a$ concentration. When normalized to $\mathrm{Chl}$ $a$, AP activity is relatively high, though variable, in the southern half of the transect and steadily decreases northward of $30^{\circ} \mathrm{N}$ (Figure $3 \mathrm{~A}$ ). This trend is inversely related to the SRP concentrations with higher AP activities in the south where the SRP is low. There is not as obvious a latitudinal trend when AP activity is considered on a per volume basis (Figure 3B). However, highest AP activities were observed between 28 and $36^{\circ} \mathrm{N}$ with a single-point peak at $34^{\circ} \mathrm{N}$, corresponding to the transition zone from permanent stratification to seasonally mixed waters and encompassing the portion of the Sargasso Sea where dissolved N:P ratios are highest $\left(\left[\mathrm{NO}_{3}+\mathrm{NO}_{2}\right]\right.$ : $[\mathrm{SRP}]$ up to $70 \mathrm{~mol} \mathrm{~mol}^{-1}$ [CavenderBares et al., 2001]). There was no AP activity observed in the $<0.4 \mu \mathrm{m}$ fraction for the three stations where it was assayed (data not shown). This is consistent with the majority of AP activity being associated with cell surfaces rather than the dissolved fraction.

\subsection{Zinc and Cobalt}

[22] Total dissolved $\mathrm{Zn}$ concentrations along the transect ranged from undetectable (average detection limit was 0.08 nmol L ${ }^{-1}$ ) to $1.3 \mathrm{nmol} \mathrm{L}^{-1}$ (Table 2, Figure 4A). Three samples had $\mathrm{Zn}$ concentrations below the detection limit (stations 12, 14, 16). Moving away from the Massachusetts coast, $\mathrm{Zn}$ concentrations dropped sharply from $1.3 \mathrm{nmol} \mathrm{L}-1$ 
Table 2. Near-Surface $(\sim 10 \mathrm{~m})$ Data From the March-April 2004 Transect $^{\mathrm{a}}$

\begin{tabular}{|c|c|c|c|c|c|c|c|c|c|}
\hline$\underline{\text { St. }}$ & Date & Location & Sal & SST $\left({ }^{\circ} \mathrm{C}\right)$ & Chl $a\left(\mu \mathrm{g} \mathrm{L}^{-1}\right)$ & $\mathrm{Co}_{T}\left(\mathrm{pmol} \mathrm{L}^{-1}\right)$ & $\mathrm{Zn}_{T}\left(\mathrm{nmol} \mathrm{L}^{-1}\right)$ & $\mathrm{SRP}\left(\mathrm{nmol} \mathrm{L}^{-1}\right)$ & $\mathrm{DOP}\left(\mathrm{nmol} \mathrm{L}^{-1}\right)$ \\
\hline 1 & $20 \mathrm{Mar}$ & $31^{\circ} 41^{\prime} \mathrm{N}, 64^{\circ} 11^{\prime} \mathrm{W}$ & 37.3 & 20.7 & $0.06(0.02)$ & $20.0(1.2)$ & $0.21(0.01)$ & $3.6(1.1)$ & $60.2(5.0)$ \\
\hline 2 & $21 \mathrm{Mar}$ & $28^{\circ} 46^{\prime} \mathrm{N}, 62^{\circ} 57^{\prime} \mathrm{W}$ & 37.4 & 20.8 & 0.02 & $10.9(0.9)$ & $0.19(0.06)$ & $1.0(0.4)$ & $92.2(3.1)$ \\
\hline 3 & $21 \mathrm{Mar}$ & $28^{\circ} 03^{\prime} \mathrm{N}, 62^{\circ} 37^{\prime} \mathrm{W}$ & 37.4 & 22.3 & 0.02 & n.d. & n.d. & $4.5(0.6)$ & $88.4(13.0)$ \\
\hline 4 & $22 \mathrm{Mar}$ & $25^{\circ} 24^{\prime} \mathrm{N}, 61^{\circ} 09^{\prime} \mathrm{W}$ & 37.4 & 24.7 & 0.03 & $10.4(0.4)$ & $0.15(0.01)$ & $3.7(4.9)^{\mathrm{b}}$ & $72.8(15.0)^{\mathrm{b}}$ \\
\hline 5 & $23 \mathrm{Mar}$ & $25^{\circ} 23^{\prime} \mathrm{N}, 61^{\circ} 08^{\prime} \mathrm{W}$ & 37.4 & 24.7 & 0.02 & $16.2(5.3)$ & $0.42(0.03)^{\mathrm{c}}$ & $<1.4$ & $105.0(11.8)$ \\
\hline 6 & 24 Mar & $22^{\circ} 48^{\prime} \mathrm{N}, 58^{\circ} 56^{\prime} \mathrm{W}$ & 37.6 & 25.2 & 0.03 & $8.4(1.4)$ & $0.26(0.04)^{\mathrm{c}}$ & $<1.4$ & $123.8(18.2)$ \\
\hline 7 & $25 \mathrm{Mar}$ & $20^{\circ} 00^{\prime} \mathrm{N}, 57^{\circ} 00^{\prime} \mathrm{W}$ & 37.9 & 25.0 & 0.04 & $6.8(0.7)$ & $0.58(0.03)^{\mathrm{c}}$ & $13.6(4.9)^{\mathrm{b}}$ & $81.1(26.5)^{b}$ \\
\hline 8 & $26 \mathrm{Mar}$ & $20^{\circ} 00^{\prime} \mathrm{N}, 52^{\circ} 58^{\prime} \mathrm{W}$ & 37.8 & 25.4 & 0.05 & $7.1(2.2)$ & $0.09(0.01)$ & $1.7(0.1)$ & $196.4(21.9)$ \\
\hline 9 & 27 Mar & $20^{\circ} 00^{\prime} \mathrm{N}, 49^{\circ} 44^{\prime} \mathrm{W}$ & 37.8 & 25.0 & 0.02 & $5.4(0.3)$ & $0.12(0.02)$ & $2.0(0.4)$ & $96.7(12.9)$ \\
\hline 10 & $28 \mathrm{Mar}$ & $20^{\circ} 00^{\prime} \mathrm{N}, 45^{\circ} 54^{\prime} \mathrm{W}$ & 37.8 & 24.6 & 0.06 & $3.8(0.0)$ & $0.15(0.02)$ & $5.8(4.9)^{\mathrm{b}}$ & $136.8(8.6)^{\mathrm{b}}$ \\
\hline 11 & 29 Mar & $20^{\circ} 58^{\prime} \mathrm{N}, 46^{\circ} 54^{\prime} \mathrm{W}$ & 37.8 & 24.8 & $0.06(0.00)$ & $4.7(0.9)$ & $0.34(0.04)^{\mathrm{c}}$ & $1.6(0.4)$ & $135.0(34.4)$ \\
\hline 12 & $30 \mathrm{Mar}$ & $23^{\circ} 36^{\prime} \mathrm{N}, 49^{\circ} 41^{\prime} \mathrm{W}$ & 37.7 & 25.4 & $0.05(0.02)$ & $8.7(4.7)$ & $<0.12$ & $3.3(0.4)$ & $118.3(21.3)$ \\
\hline 13 & $1 \mathrm{Apr}$ & $28^{\circ} 31^{\prime} \mathrm{N}, 53^{\circ} 11^{\prime} \mathrm{W}$ & 37.4 & 21.9 & $0.05(0.00)$ & $10.1(2.6)$ & $0.37(0.04)^{\mathrm{c}}$ & $1.7(0.7)$ & $74.30(14.8)$ \\
\hline 14 & $1 \mathrm{Apr}$ & $29^{\circ} 38^{\prime} \mathrm{N}, 53^{\circ} 37^{\prime} \mathrm{W}$ & 37.2 & 20.6 & 0.06 & $13.7(0.1)$ & $<0.07$ & $3.2(0.8)$ & $104.5(16.1)$ \\
\hline 15 & $2 \mathrm{Apr}$ & $32^{\circ} 14^{\prime} \mathrm{N}, 54^{\circ} 37^{\prime} \mathrm{W}$ & 37.4 & 20.4 & $0.12(0.00)$ & $18.0(0.5)$ & $0.18(0.05)$ & $3.2(0.2)$ & $108.4(0.0)$ \\
\hline 16 & $4 \mathrm{Apr}$ & $34^{\circ} 38^{\prime} \mathrm{N}, 55^{\circ} 35^{\prime} \mathrm{W}$ & 37.2 & 19.0 & $0.27(0.07)$ & $14.3(1.6)$ & $<0.12$ & $2.9(0.2)$ & $89.9(0.0)$ \\
\hline 17 & $5 \mathrm{Apr}$ & $34^{\circ} 24^{\prime} \mathrm{N}, 58^{\circ} 12^{\prime} \mathrm{W}$ & 37.0 & 19.0 & $0.37(0.17)$ & $13.9(0.9)$ & $0.11(0.01)$ & $6.3(1.5)$ & $73.5(16.1)$ \\
\hline 18 & $6 \mathrm{Apr}$ & $36^{\circ} 11^{\prime} \mathrm{N}, 61^{\circ} 54^{\prime} \mathrm{W}$ & 37.1 & 18.1 & $0.51(0.08)$ & $43.0(3.5)$ & $0.08(0.02)$ & $66.5(2.4)$ & $84.8(7.4)$ \\
\hline 19 & $7 \mathrm{Apr}$ & $37^{\circ} 43^{\prime} \mathrm{N}, 64^{\circ} 51^{\prime} \mathrm{W}$ & 36.8 & 19.2 & $0.49(0.06)$ & $39.9(5.2)$ & $0.14(0.06)$ & $22.5(1.1)$ & $168.9(17.0)$ \\
\hline 20 & $8 \mathrm{Apr}$ & $38^{\circ} 42^{\prime} \mathrm{N}, 67^{\circ} 07^{\prime} \mathrm{W}$ & 37.0 & 19.5 & $0.61(0.14)$ & $51.5(1.9)$ & $0.35(0.05)$ & $103.3(2.8)$ & $50.8(0.0)$ \\
\hline 21 & $8 \mathrm{Apr}$ & $38^{\circ} 56^{\prime} \mathrm{N}, 67^{\circ} 33^{\prime} \mathrm{W}$ & 36.3 & 14.1 & $0.55(0.08)$ & $51.8(0.1)$ & $0.24(0.02)$ & $400.4(9.1)$ & $223.3(34.4)$ \\
\hline 22 & $8 \mathrm{Apr}$ & $38^{\circ} 59^{\prime} \mathrm{N}, 67^{\circ} 38^{\prime} \mathrm{W}$ & 35.5 & 8.0 & $1.40(0.20)$ & $56.3(1.7)$ & $0.44(0.03)$ & $342.6(37.9)$ & $216.0(18.7)$ \\
\hline 23 & $8 \mathrm{Apr}$ & $39^{\circ} 23^{\prime} \mathrm{N}, 68^{\circ} 35^{\prime} \mathrm{W}$ & 34.1 & 8.4 & $1.80(0.59)$ & $90.9(24.9)$ & $0.96(0.02)$ & $584.8(42.1)$ & $233.9(22.2)$ \\
\hline 24 & 9 Apr & $40^{\circ} 00^{\prime} \mathrm{N}, 70^{\circ} 01^{\prime} \mathrm{W}$ & 34.1 & 6.7 & $1.87(0.15)$ & $111.4(18.1)$ & $0.69(0.10)$ & $416.1(9.4)$ & $282.4(24.1)$ \\
\hline 25 & $9 \mathrm{Apr}$ & $40^{\circ} 27^{\prime} \mathrm{N}, 70^{\circ} 19^{\prime} \mathrm{W}$ & 33.5 & 5.1 & $0.84(0.02)$ & $59.9(5.7)$ & $1.32(0.08)$ & $452.6(38.2)$ & $307.5(32.1)$ \\
\hline
\end{tabular}

${ }^{a}$ Values in parentheses represent the standard deviation of duplicate filters for Chl $a$, triplicate analyses for SRP and DOP, and either duplicate or triplicate analyses for Co and $\mathrm{Zn}$. For Chl $a$, where there are no values in parentheses, only one filter was collected. Zn and SRP values that fell below the detection limit are marked $<$ daily detection limit. Sal $=$ salinity, SST $=$ sea surface temperature, n.d. $=$ not determined.

${ }^{\mathrm{b}}$ From Dyhrman et al. [2006]; these data are not included in subsequent figures.

${ }^{\mathrm{c}}$ Contamination suspected; these data are not included in subsequent figures.

to $0.14 \mathrm{nmol} \mathrm{L} \mathrm{L}^{-1}$. Zinc concentrations in the middle of the transect oscillated between undetectable values and $0.42 \mathrm{nmol} \mathrm{L}^{-1}$ without an obvious spatial trend (Table 2). Along $20^{\circ} \mathrm{N}$ latitude, $\mathrm{Zn}$ concentrations were very low $\left(\sim 0.1 \mathrm{nmol} \mathrm{L} \mathrm{L}^{-1}\right)$ except for the western most station $\left(0.58 \mathrm{nmol} \mathrm{L}{ }^{-1}\right)$. That station and four others $(5,6,11$, and 13) are suspected of contamination (see Discussion). The measured values of these stations are reported in Table 2 but have been omitted from all figures. Dissolved Co was detectable at all stations and ranged from 3.8 to $111.4 \mathrm{pmol} \mathrm{L}^{-1}$ (Table 2, Figure 4B). Total Co concentrations also decreased away from the Massachusetts coast, though the Co concentration gradient encompassed a larger latitudinal span than that of $\mathrm{Zn}$. Cobalt decreased more gradually and consistently with latitude than $\mathrm{Zn}$ with the lowest Co concentrations $\left(3.8-7.1 \mathrm{pmol} \mathrm{L}^{-1}\right)$ measured at the most southern latitude $\left(20^{\circ} \mathrm{N}\right)$.

[23] Correlations between Chl $a$ and Co, Zn, and SRP (Figure 5) were examined by linear regression analysis. Chl $a$ concentrations were highly correlated with Co concentrations $\left(R^{2}=0.90\right)$ and by lesser degrees with SRP $\left(R^{2}=\right.$ $0.78)$ and $\mathrm{Zn}\left(R^{2}=0.51\right.$, anomalously high $\mathrm{Zn}$ values not included). When the concentrations of SRP are compared with those of Co (Figure 6A) and Zn (Figure 6B), positive relationships are seen. The correlation between Co and SRP is stronger $\left(R^{2}=0.78\right)$ than that of $\mathrm{Zn}$ and $\mathrm{SRP}\left(R^{2}=0.72\right.$, anomalously high $\mathrm{Zn}$ values not included).

\subsection{Culture Study}

[24] We examined the influence of $\mathrm{Co}$ and $\mathrm{Zn}$ on $\mathrm{AP}$ activity in batch cultures grown over a range of $\mathrm{Zn}, \mathrm{Co}$, and
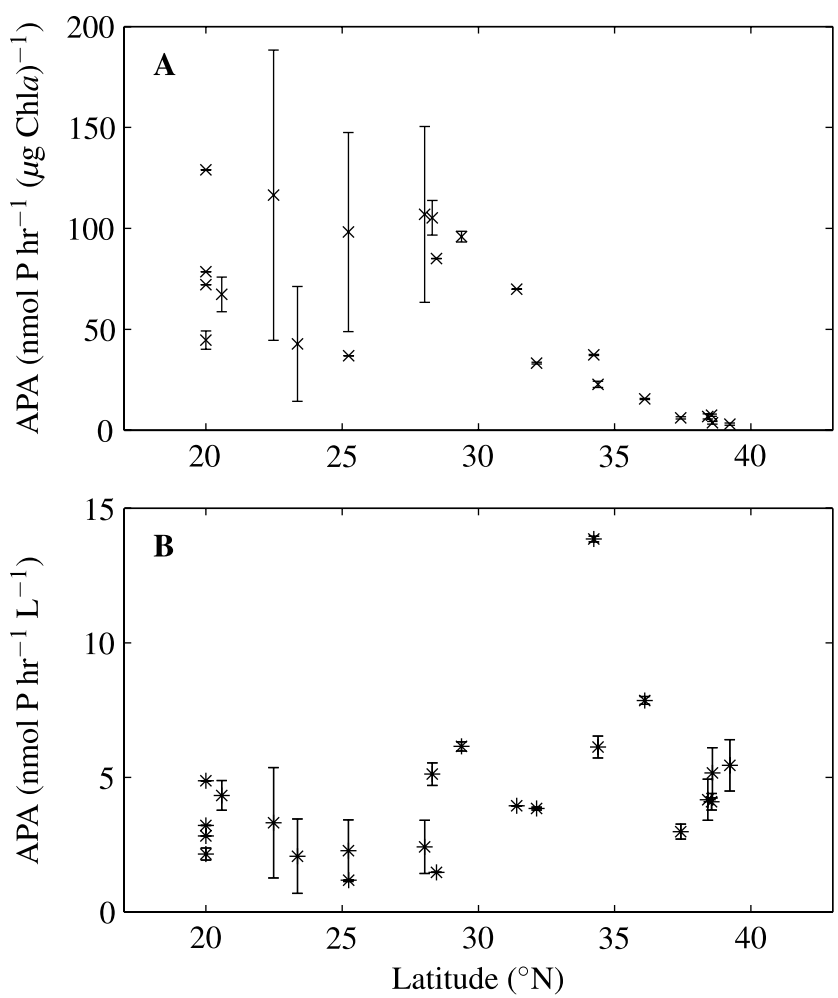

Figure 3. Alkaline phosphatase activity (APA) at approximately $10 \mathrm{~m}$ along the transect. In Figure $3 \mathrm{~A}$ activities are normalized to the Chlorophyll $a$ concentration, whereas in Figure $3 \mathrm{~B}$, activities are presented on a per volume basis. 

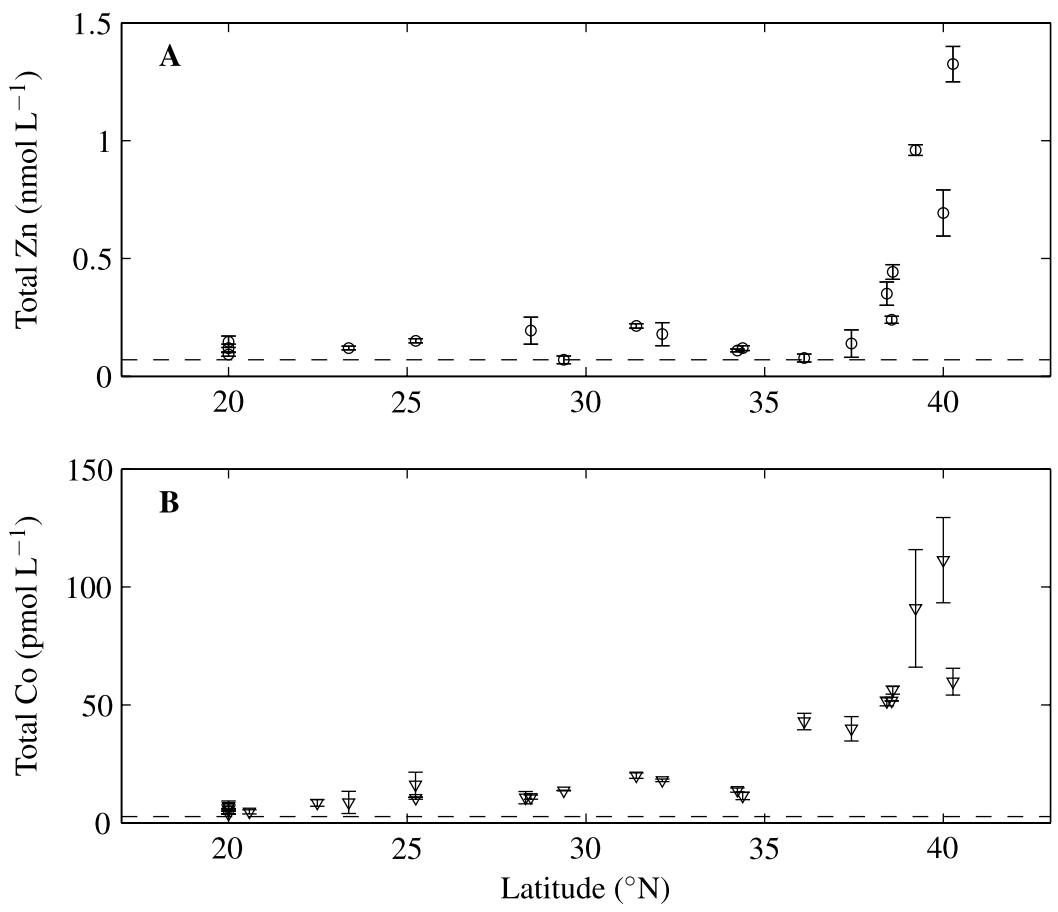

Figure 4. Concentrations of total dissolved (A) $\mathrm{Zn}$ and (B) Co at roughly $10 \mathrm{~m}$ depth along the transect. Error bars represent the standard deviation of duplicate or triplicate analyses. Detection limit of the analyses is denoted by the dashed line. Any values which fell below the detection limit are plotted with the detection limit as their concentration.

P conditions. The model coccolithophore E. huxleyi was used as it has been well characterized with regards to metal requirements [Sunda and Huntsman, 1995] and AP activity [Dyhrman and Palenik, 2003; Landry et al., 2006; Xu et al., 2006]. The growth rate of E. huxleyi was highest in the $+\mathrm{Zn} /$ + Co treatments and significantly decreased from the $-\mathrm{Zn}$ to the $-\mathrm{Co}$ to the $-\mathrm{Zn} /-\mathrm{Co}$ treatments at both $\mathrm{P}$ conditions (Figures 7A and 7B). This trend in growth rates follows the pattern of previous culture studies [Sunda and Huntsman, 1995], where coccolithophores have a primary growth requirement for $\mathrm{Co}$ that can be partially substituted with
$\mathrm{Zn}$. In both the $-\mathrm{Zn}$, low-P and $-\mathrm{Co}$, low-P treatments, the maximum AP activity was reduced to only $60 \%$ of the maximum activity in the $+\mathrm{Zn} /+\mathrm{Co}$, low-P treatment (Figure 7C). This trend also holds when the average AP activity of 4 days is considered (data not shown). AP activity in the $-\mathrm{Zn} /-\mathrm{Co}$, low-P treatment was generally undetectable. For the high-P treatments, AP activity was either extremely low or non-detectable (Figure 7D). The re-addition of $\mathrm{P}$ to the $+\mathrm{Zn} /+\mathrm{Co}$, low-P; $-\mathrm{Zn}$, low-P; and - Co, low-P treatments caused a decrease in AP activity within 24 hours of re-addition (data not shown), similar
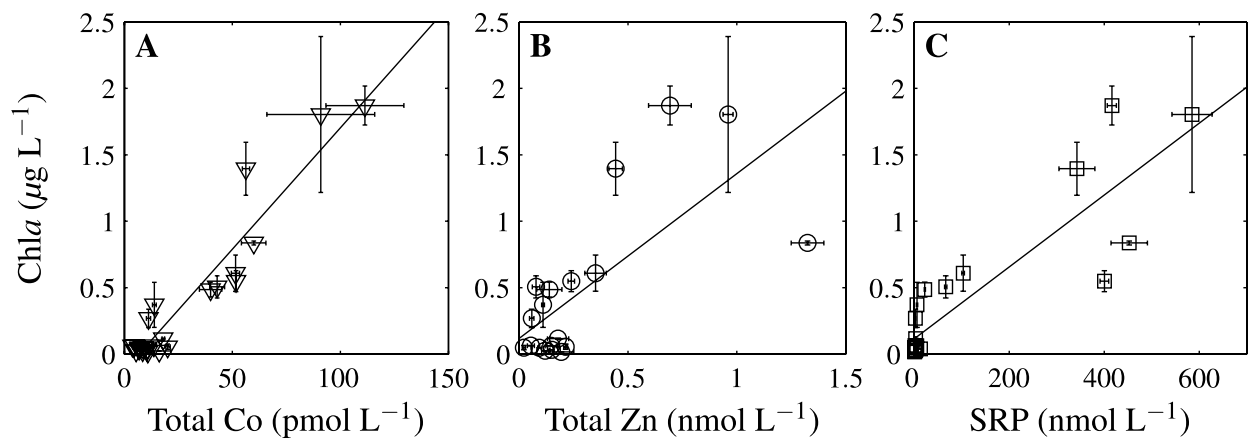

Figure 5. Relationship between Chlorophyll $a$ concentration and the concentrations of total dissolved (A) $\mathrm{Co}$, (B) $\mathrm{Zn}$ and (C) soluble reactive phosphorus. Co and $\mathrm{Zn}$ error bars represent the standard deviation of duplicate or triplicate analyses. SRP error bars represent the standard deviation of triplicate analyses. Chl $a$ error bars represent the standard deviation of duplicate filters. Lines are least-squares fit lines $\left(R^{2}\right.$ values are 0.90 for $\mathrm{Co} / \mathrm{Chl} a, 0.51$ for $\mathrm{Zn} / \mathrm{Chl} a$, and 0.78 for $\mathrm{SRP} / \mathrm{Chl} a$ ). 

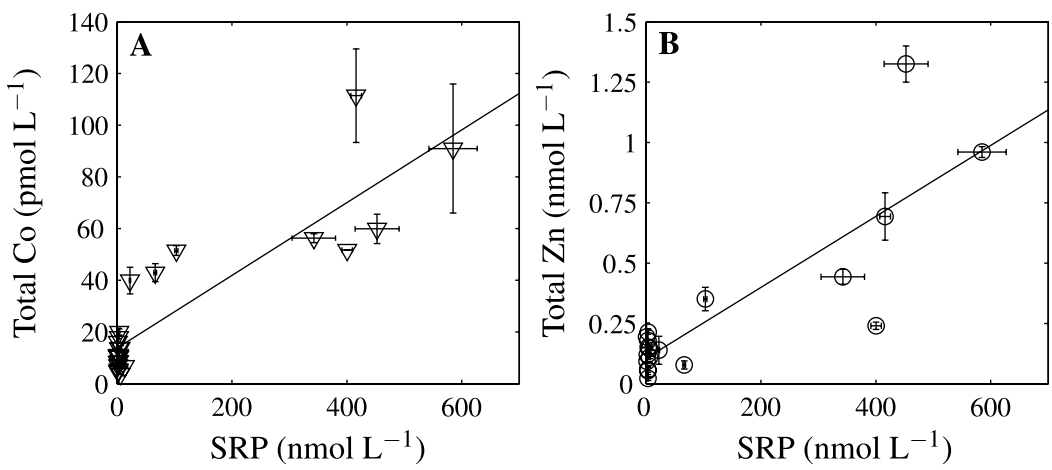

Figure 6. Relationship between soluble reactive phosphorus concentration and the concentrations of total dissolved (A) Co and (B) Zn. Error bars as with previous figures. Lines are least-squares fit lines $\left(R^{2}\right.$ values are 0.78 for $\mathrm{Co} / \mathrm{SRP}$ and 0.72 for $\mathrm{Zn} / \mathrm{SRP})$.

to previous studies of AP activity in E. huxleyi [Dyhrman and Palenik, 2003].

[25] The concentration of SRP at the end of the experiment in all of the high-P treatments was above our highest standard $\left(1 \mu \mathrm{mol} \mathrm{L} \mathrm{L}^{-1}\right)$. There was no detectable SRP $\left(<20 \mathrm{nmol} \mathrm{L}{ }^{-1}\right)$ at the end of the experiment in the $+\mathrm{Zn} /$ $+\mathrm{Co}$, low-P; $-\mathrm{Zn}$, low-P; and $-\mathrm{Co}$, low-P treatments. In the $-\mathrm{Zn} /-\mathrm{Co}$, low-P treatment, there was $592 \pm 30 \mathrm{nmol} \mathrm{L}{ }^{-1}$ SRP left in the media at the end of the experiment. The low growth observed and the relatively high levels of SRP remaining in the $-\mathrm{Zn} /-\mathrm{Co}$, low-P media suggest that SRP was not sufficiently drawn down to induce AP activity. Thus the absence of activity in the $-\mathrm{Zn} /-$ Co treatment may be due to P-sufficient conditions rather than metal limitation of AP.

\section{Discussion}

[26] This study provides a uniquely comprehensive data set of Chl $a$, SRP, DOP, AP activity, Co, and $\mathrm{Zn}$ on the same suite of samples covering a large section of the western North Atlantic Ocean. Previous measurements of total dissolved $\mathrm{Zn}$ in the surface waters of the North Atlantic range from $0.06-0.34 \mathrm{nmol} \mathrm{L}^{-1}$ in the open ocean to $0.59-$ $2.4 \mathrm{nmol} \mathrm{L}^{-1}$ closer to the coast [Bruland and Franks, 1983; Martin et al., 1993; Ellwood and van den Berg, 2000]. Our measurements of $<0.07-1.32 \mathrm{nmol} \mathrm{L}^{-1}$ agree
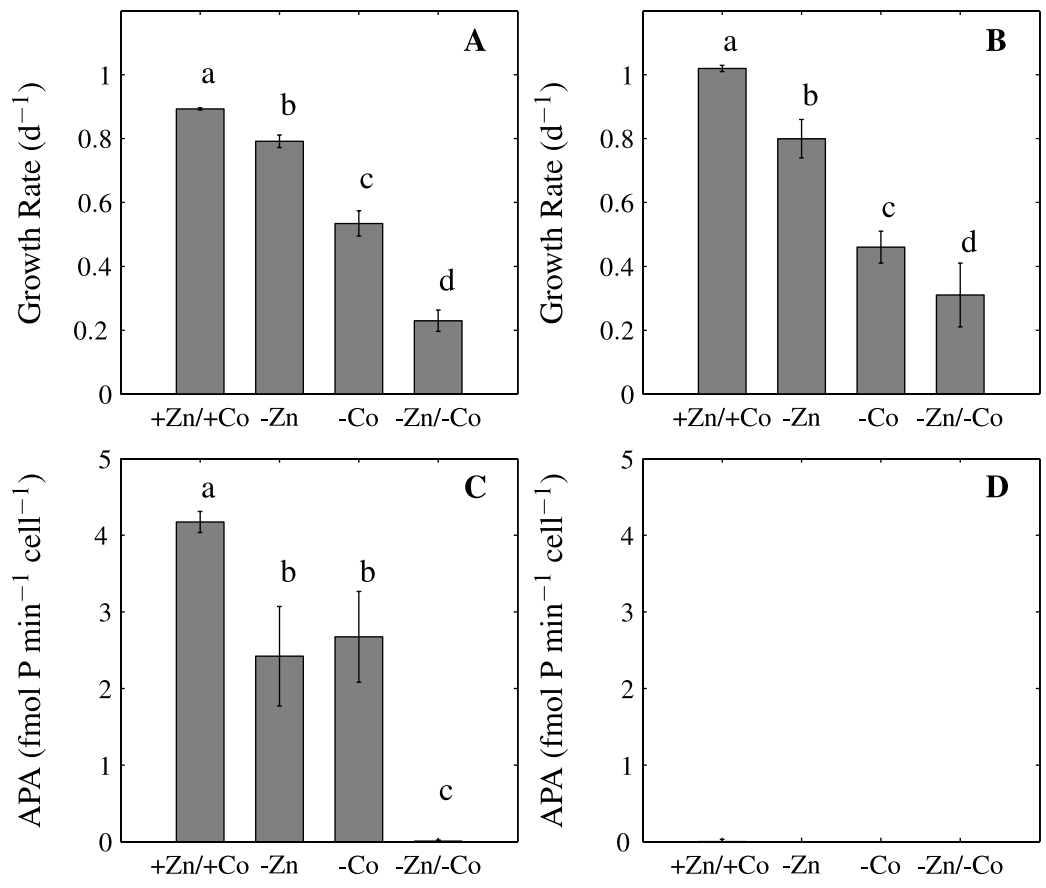

Figure 7. (A, B) Growth rate and (C, D) maximum AP activity of E. huxleyi. Data represent culture conditions over varying levels of $\mathrm{Zn}$ and $\mathrm{Co}$ and two different $\mathrm{P}$ levels (7A, 7C: low P; 7B, 7D: high P). Average values of triplicate cultures are plotted for each treatment with the standard deviation plotted as error bars. Statistically different values are indicated by different letters above the bar. Note that in the high DIP treatments (7D), AP activity is negligible regardless of the metal treatment. 
well with these previous studies. The concentrations of $\mathrm{Co}$ observed (3.8-111.4 pmol $\left.\mathrm{L}^{-1}\right)$ also agree well with previous measurements [Martin et al., 1993; Saito and Moffett, 2002], though the concentrations in this study (usually $<20 \mathrm{pmol} \mathrm{L}^{-1}$ ) fell mainly in the lower range of previous observations. Surface water concentrations of $\mathrm{Zn}$ and $\mathrm{Co}$ can be influenced by a variety of processes including biological uptake and remineralization, lateral and deep-water mixing, and atmospheric deposition. Much of the observed spatial variability in $\mathrm{Zn}$ and Co surface distributions is consistent with hypotheses concerning biological uptake.

[27] The concentrations of $\mathrm{Zn}$ and Co appeared to be decoupled along parts of the transect. Moving offshore (36$\left.40^{\circ} \mathrm{N}\right), \mathrm{Zn}$ concentrations decreased more dramatically at the northern stations than Co concentrations. In culture studies, cellular Co uptake rates of diatoms and coccolithophores increased with decreasing concentrations of free $\mathrm{Zn}^{2+}$ [Sunda and Huntsman, 1995]. Concentrations of dissolved $\mathrm{Co}$ in the subarctic North Pacific only appear to be drawn down with $\mathrm{N}$ and $\mathrm{P}$ once $\mathrm{Zn}$ concentrations are depleted [Sunda and Huntsman, 1995]. These prior studies are consistent with the observed depletion of $\mathrm{Zn}$ relative to $\mathrm{Co}$, and with Co depletion where $\mathrm{Zn}$ is low, which could be due to increased Co uptake once $\mathrm{Zn}$ concentrations are low. Another possibility is that the concentration trends indicate a higher biological demand for $\mathrm{Zn}$ than $\mathrm{Co}$ in the most northern part of the transect. The northern part of the study area encompassed colder continental shelf waters and the northern Sargasso Sea, waters where diatoms can account for the majority of Chl $a$ in the spring [Siegel et al., 1990]. Diatoms have a high $\mathrm{Zn}$ requirement and little or no absolute Co requirement [Sunda and Huntsman, 1995]. The presence of a diatom-dominated community between $36-40^{\circ} \mathrm{N}$ may have contributed to the more dramatic $\mathrm{Zn}$ drawdown relative to $\mathrm{Co}$ in this region. Alternately, the concentration of trace metals may act as a selective factor [Brand et al., 1983], and species better adapted for higher $\mathrm{Zn}$ conditions will predominate in the north.

[28] There were several stations in the south where $\mathrm{Zn}$ concentrations increased without a corollary increase in Co. South of $30^{\circ} \mathrm{N}$, the $\mathrm{Zn}$ concentration was generally less than $0.2 \mathrm{nmol} \mathrm{L}{ }^{-1}$; however, at five stations $(5,6,7,11$, and 13$)$ relatively high $\mathrm{Zn}$ concentrations were observed (0.26-0.58 nmol $\left.\mathrm{L}^{-1}\right)$. There was no comparable increase in Co concentration at these stations. One explanation for this discrepancy is that $\mathrm{Zn}$ contamination may have occurred during sampling. Zinc is a very contamination prone element, and while great care was taken to prevent contamination, the anomalously high $\mathrm{Zn}$ values were generally at the beginning of the cruise, a time when shipboard contamination issues are not always resolved. In an attempt to determine whether the high $\mathrm{Zn}$ values were real or the result of contamination, six samples collected from the same region by another investigator were measured. The samples were collected by underway or pole samplers in July 2005 from $16-24^{\circ} \mathrm{N}$ and generously provided by Ed Boyle (Massachusetts Institute of Technology). The total dissolved Zn concentration in all six samples was less than $0.09 \mathrm{nmol}$ $\mathrm{L}^{-1}$. These results suggest that the high $\mathrm{Zn}$ values we observed in the southern Sargasso Sea are not a common feature and likely reflect sampling contamination. The two sets of samples were collected at different times of year, on different cruises, and at different (though similar) locations, so it is possible that the discrepancy reflects true variability. For instance, in the southern Sargasso Sea, where picocyanobacteria typically dominate the biomass, the residence time of $\mathrm{Zn}$ in the surface layer may be enhanced relative to the northern Sargasso Sea because picocyanobacteria have a relatively low biological demand for $\mathrm{Zn}$. The two most abundant picocyanobacteria, Synechococcus and Prochlorococcus, both have absolute growth requirements for $\mathrm{Co}$ that cannot be fully substituted for with Zn [Sunda and Huntsman, 1995; Saito et al., 2002]. Dust deposition from the Sahara is an important source of iron to the North Atlantic Ocean [e.g., Duce and Tindale, 1991] and dust deposition would be anticipated to have a larger influence closer to its source (i.e., in the southern portion of transect). However, $\mathrm{Zn}$ is a thousand-fold less abundant than iron in crustal material [Taylor and McLennan, 1985], and the importance of eolian deposition of $\mathrm{Zn}$ to the surface ocean is not as well understood. Dust deposition does not appear to be a significant source of Co to the North Atlantic [Saito and Moffett, 2002]. Large-scale sampling efforts such as the GEOTRACES program should help clarify the above issues [Henderson et al., 2007].

[29] In a previous study in the North Atlantic, Co concentrations were tightly coupled to salinity [Saito and Moffett, 2002] suggesting that Co concentrations may largely reflect conservative mixing between the high-salinity waters of the Sargasso Sea with low-salinity shelf waters. In contrast, the relationship between $\mathrm{Zn}$ concentrations and salinity suggested possible removal of $\mathrm{Zn}$ relative to that expected based only on conservative mixing [Bruland and Franks, 1983]. The relationship between $\mathrm{Co}$ and salinity from stations 17 to 25 was similar to that described in Saito and Moffett when the low Co concentration at station 25 was ignored, but the scatter in the data make it difficult to ascertain whether or not $\mathrm{Co}$ is behaving conservatively. Similar to previous work, the $\mathrm{Zn}$ concentrations in this study suggest that $\mathrm{Zn}$ may be removed relative to conservative mixing. Taken together, these relationships are consistent with the hypothesis that there may be a higher biological demand for $\mathrm{Zn}$ than for $\mathrm{Co}$ in the northern portion of our transect.

[30] The correlation between Chl $a$ and Co observed in this study is noteworthy because it is so strong $\left(R^{2}=0.90\right)$. In particular, it is stronger than the correlation with salinity noted here $\left(R^{2}=0.82\right)$. While it is impossible to establish a causal relationship between $\mathrm{Co}$ and biology from this correlation alone, it suggests that there may be significant biological utilization of Co over the entire transect and that Co is either limiting phytoplankton growth or, more likely, that it is closely correlated with other factors that are. At the very least, the data suggest significant biological utilization of cobalt, even when SRP is high, confirming that the community's Co demand is not based exclusively on AP or links to the P cycle. Synechococcus and Prochlorococcus both have absolute Co requirements at high SRP concentrations [Sunda and Huntsman, 1995; Saito et al., 2002] 
Table 3. Regression Slopes of $\mathrm{Co}$ and $\mathrm{Zn}$ Versus $\mathrm{PO}_{4}\left(\mu \mathrm{mol} \mathrm{mol}{ }^{-1}\right)$ in the Upper Water Column [After Sunda and Huntsman, 1995; Saito and Moffett, 2002]

\begin{tabular}{lccccc}
\hline \multicolumn{1}{c}{ Location } & Depth $(\mathrm{m})$ & $\Delta \mathrm{Co} / \Delta \mathrm{P}$ & $\Delta \mathrm{Zn} / \Delta \mathrm{P}$ & $\left.\mathrm{SRP}(\mu \mathrm{mol} \mathrm{L})^{-1}\right)$ & Reference \\
\hline Northeast Pacific $\left(39.6^{\circ} \mathrm{N}, 140.8^{\circ} \mathrm{W}\right)$ & $50-150$ & 39.8 & 251 & $0.23-0.87$ & Martin et al. $[1989]$ \\
Northeast Pacific $\left(45.0^{\circ} \mathrm{N}, 142.9^{\circ} \mathrm{W}\right)$ & $20-100$ & 35.5 & 373 & $0.65-0.99$ & Martin et al. $[1989]$ \\
Northeast Pacific $\left(55.5^{\circ} \mathrm{N}, 147.5^{\circ} \mathrm{W}\right)$ & $8-50$ & 38.4 & 255 & $0.40-1.2$ & Martin et al. $[1989]$ \\
Northeast Pacific $\left(35.8^{\circ} \mathrm{N}, 122.6^{\circ} \mathrm{W}\right)$ & $0-195$ & $\mathrm{a}$ & $\mathrm{b}$ & $0.43-2.1$ & Martin and Gordon [1988] \\
Northeast Pacific $\left(35.1^{\circ} \mathrm{N}, 128.2^{\circ} \mathrm{W}\right)$ & $0-200$ & 25.0 & $\mathrm{~b}$ & $0.062-1.4$ & Martin and Gordon [1988] \\
Northeast Pacific $\left(33.3^{\circ} \mathrm{N}, 139.1^{\circ} \mathrm{W}\right)$ & $0-195$ & 25.3 & $\mathrm{~b}$ & $0.00-0.58$ & Martin and Gordon [1988] \\
North Atlantic transect & Surface & $\mathrm{c}$ & 7870 & $0.02-0.30$ & Bruland and Franks $[1983]$ \\
North Atlantic $\left(34^{\circ} \mathrm{N}, 66^{\circ} \mathrm{W}\right)$ & $0-375$ & $\mathrm{c}$ & 1861 & $0.03-0.16$ & Bruland and Franks $[1983]$ \\
Northeast Atlantic $\left(59^{\circ} \mathrm{N}, 20^{\circ} \mathrm{W}\right)$ & $20-100$ & 10.5 & 593 & $0.50-1.0$ & Martin et al. $[1993]$ \\
Northeast Atlantic $\left(47^{\circ} \mathrm{N}, 20^{\circ} \mathrm{W}\right)$ & $20-150$ & 45.0 & 1885 & $0.05-0.54$ & Martin et al. $[1993]$ \\
South Atlantic transect & 5 & 560 & $\mathrm{~b}$ & $0.04-0.15$ & Saito and Moffett [2002] \\
Sargasso Sea transect & 10 & 137 & 1461 & $0.001-0.45$ & This study \\
\hline
\end{tabular}

${ }^{\mathrm{a}}$ No correlation between $\mathrm{Co}$ and $\mathrm{PO}_{4}$ observed.

${ }^{\mathrm{b}}$ No $\mathrm{Zn}$ data available.

${ }^{\mathrm{c}}$ No Co data available.

because of Co's role in various cellular components and processes including vitamin $\mathrm{B}_{12}$ synthesis and carbonic anhydrase [Lane and Morel, 2000; Saito et al., 2003]. In addition, Co uptake is enhanced in other species when $\mathrm{Zn}$ concentrations are low, regardless of SRP concentration [e.g., Sunda and Huntsman, 1995].

[31] Using data from this study and others, regression slopes of $\mathrm{Co}$ and $\mathrm{Zn}$ versus phosphate were calculated for the Atlantic and North Pacific in the upper water column $(0-375 \mathrm{~m})$ where biological uptake processes typically determine the dissolved concentration of nutrient-type elements (Table 3). The $\Delta \mathrm{Zn} / \Delta \mathrm{P}$ ratios observed in the Atlantic were much higher than those determined in the North Pacific. The $\Delta \mathrm{Co} / \Delta \mathrm{P}$ values were generally higher in the North Atlantic than in the North Pacific. However, the situation seems to be more complex, as one profile from the North Atlantic had a very low $\Delta \mathrm{Co} / \Delta \mathrm{P}$, and in another, no correlation between $\mathrm{Co}$ and $\mathrm{P}$ was observed (Table 3 ). Concentrations of SRP in the mixed layer of the North Pacific are typically an order of magnitude higher than those observed in the North Atlantic [e.g., Cavender-Bares et al., 2001]. The higher apparent uptake of $\mathrm{Co}$ and $\mathrm{Zn}$, relative to $\mathrm{P}$, in the North Atlantic may be due in part to an elevated demand for $\mathrm{Zn}$ and $\mathrm{Co}$ associated with AP in the Atlantic where SRP is typically depleted.

[32] It is important to note that all of the Pacific data were derived from upper water column depth profiles, while half of the Atlantic data are from surface water transects, so they must be compared cautiously. Nevertheless, the $\Delta \mathrm{Zn} / \Delta \mathrm{P}$ values determined from two of the North Atlantic profiles [Bruland and Franks, 1983; Martin et al., 1993] are very similar to our transect value. Furthermore, assuming Redfield C:P stoichiometry, we can estimate a Co to carbon (C) ratio in the ambient microplankton from our $\Delta \mathrm{Co} / \Delta \mathrm{P}$ ratio of $1.4 \mu \mathrm{mol} \mathrm{Co}$ per mol C. This is very close to the value of $1.5 \mu \mathrm{mol}$ Co per mol C measured by Sherrell and Boyle [1992] for surface $(10-100 \mathrm{~m})$ particulate matter in the Sargasso Sea. This agreement provides further support to the idea that variations in $\mathrm{Co}$ and $\mathrm{P}$ concentrations are primarily linked to uptake and removal by biogenic particles, most likely phytoplankton. Moffett and Ho [1996] showed that Co uptake by particles in surface waters of the Sargasso Sea is almost entirely a light-dependent biological process (i.e., due to uptake by phytoplankton) and that abiotic particulate uptake or microbial oxidation was negligible. Consequently, it is reasonable to propose that the stronger drawdown observed in the Atlantic (Table 3) might reflect a higher biological demand for both $\mathrm{Co}$ and $\mathrm{Zn}$ associated with the much lower values of SRP in the Atlantic. Clearly, however, more data are required to validate this hypothesis, particularly considering that the lack of metal data associated with low SRP data and the difference in surface SRP values in the Atlantic and Pacific basins make comparing these ratios across the same SRP range difficult.

[33] The difference in $\Delta \mathrm{Co} / \Delta \mathrm{P}$ between basins may also be impacted by differences in deep-water ratios. Because Co is scavenged onto settling particles in deep ocean waters, its concentration is lower in older deep Pacific waters than in younger deep Atlantic waters [Saito and Moffett, 2002; Martin and Gordon, 1988], whereas $\mathrm{Zn}$ and $\mathrm{P}$, which are not readily scavenged by settling particles in deep ocean water, have higher concentrations in deep Pacific waters than in the deep Atlantic [Bruland and Franks, 1983]. Thus the Co:P ratio in the deep Pacific is much lower than in the deep Atlantic, and part of the difference in the $\Delta \mathrm{Co} / \Delta \mathrm{P}$ of surface waters may reflect the difference in deep-water ratios between basins. This will be less important for $\Delta \mathrm{Zn} / \Delta \mathrm{P}$, since there is not as large a difference in deepwater ratios between basins.

[34] Plots of $Z n$ versus SRP in the Northeast Pacific often have positive $\mathrm{x}$-axis intercepts, indicative of a drawdown of $\mathrm{Zn}$ in the presence of high SRP [Martin et al., 1989]. One explanation for this behavior is that under the low $\mathrm{Zn}$ conditions of central gyres, phytoplankton with low $\mathrm{Zn}$ requirements (and lower $\mathrm{Zn}: \mathrm{P}$ ratios) predominate. Even within one species, the uptake of $\mathrm{Zn}$ will vary with $\mathrm{Zn}$ concentration, such that when free $\mathrm{Zn}^{2+}$ is high, cells may perform "luxury uptake" beyond their immediate cellular requirement, and when free $\mathrm{Zn}^{2+}$ is low, the cells have lower internal $\mathrm{Zn}$ concentrations [Sunda and Huntsman, 2000]. This lower cellular $\mathrm{Zn}$ requirement may be achieved by substitution of other elements such as Co or cadmium (Cd) for Zn [Sunda and Huntsman, 1995, 2000]. In the Atlantic, we found the $\mathrm{Zn}$ vs SRP and Co vs SRP relationships to be somewhat different than those in the North Pacific. For plots 
of both $\mathrm{Zn}$ and Co versus SRP, there were positive $\mathrm{y}$-axis intercepts with the lowest metal concentrations found only at very low SRP concentrations (less than $\sim 10 \mathrm{nmol} \mathrm{L}^{-1}$ ). One explanation for this relationship may be that at low SRP values, elevated production of AP creates an increased demand for $\mathrm{Zn}$ and Co. If DOP utilization is not involved, the relationship could reflect a dramatic change in slope, but this would yield unrealistically high $\mathrm{Zn}$ or $\mathrm{Co}$ to $\mathrm{C}$ ratios at low P. Alternately, there may be a modest increase in Co and $\mathrm{Zn}$ cell quotas associated with the production of AP, but this results in an additional reservoir of $\mathrm{P}$ becoming available, which leads to further $\mathrm{Zn}$ and Co drawdown.

[35] If we assume that the cellular metal:P ratio remains constant, we can extrapolate to a hypothetical $\mathrm{P}$ value where all $\mathrm{Zn}$ or Co has been utilized. As discussed above, there can be plasticity in metal:nutrient ratios [Sunda and Huntsman, 1995, 2000], so this assumption is not trivial. Nevertheless, it is interesting to note that the extrapolated $\mathrm{P}$ values for both $\mathrm{Zn}$ and $\mathrm{Co}$ are similar at approximately negative 75

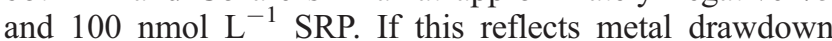
associated with DOP utilization, a true bioavailable P parameter might equal the SRP concentration plus the extrapolated SRP deficit (in the absence of other limiting factors such as N). The SRP deficit corresponds to $55-75 \%$ of the average DOP concentration from our transect. The bioavailability of the DOP pool is poorly constrained, but given the dominance of potentially bioavailable phosphate esters in high molecular weight DOP [Kolowith et al., 2001], it is not unreasonable to suppose that a significant fraction of DOP is able to support continued metal drawdown. This assumes that the high molecular weight DOP is representative of the entire DOP pool and that DOP composition is consistent across the Sargasso Sea. Further studies of DOP cycling will inform the accuracy of the above relationships to predict bioavailable $\mathrm{P}$, however evidence of the importance of DOP in supporting primary production in the Sargasso Sea is emerging [Dyhrman et al., 2006; Mather et al., 2008]. Indeed, Mather et al. [2008] interpret the relatively high AP activities and low DOP concentrations in the North Atlantic subtropical gyre to reflect $\mathrm{P}$ limitation and subsequent DOP utilization.

[36] The culture experiment described herein provides further evidence for the potential importance of both $\mathrm{Zn}$ and $\mathrm{Co}$ for $\mathrm{P}$ acquisition under low SRP conditions. Our results are consistent with the reduction in AP activity under low Zn conditions observed by Shaked et al. [2006] but also demonstrate that low Co can result in reduced AP activity in some phytoplankton species, such as E. huxleyi. These data suggest that at low $\mathrm{P}$ there may be some plasticity in the metal requirements of $E$. huxleyi $\mathrm{AP}$ and underscores the potential for both $\mathrm{Zn}$ and Co to constrain AP activity. This result highlights that at low $\mathrm{P}$, both the $\mathrm{Zn}$ and Co cycles may be linked with that of P. As such, both $\mathrm{Zn}$ and Co have the potential to influence community composition, phytoplankton P physiology, and DOP cycling.

[37] In summary, this unique data set emphasizes the potential for linkages between the biogeochemistries of $\mathrm{Zn}$, Co, and P. These data further highlights the value of data sets with sensitive measures of both trace metals and macronutrients. In particular, coupling of trace metal data with low-level P data is extremely useful in the Sargasso Sea. The culture experiment and fieldwork suggest that the biogeochemistry of $\mathrm{Co}$ and $\mathrm{Zn}$ may be coupled to that of $\mathrm{P}$ in the Sargasso Sea. Future work in this and other oligotrophic systems may help to identify the consistency of this relationship.

[38] Acknowledgments. The authors would like to thank the captain and crew of the R/V Oceanus. Thank you to Ed Boyle for generously providing extra samples for $\mathrm{Zn}$ analysis and to Mak Saito and Abigail Noble for providing the DMG reagent. Thanks to Dave Schneider of the WHOI Plasma Mass Spectrometry Facility for assistance with ICP-MS measurements and to Tyler Goepfert and Dreux Chappell for assistance at sea. The authors appreciate the thorough reviews from Bill Sunda and an anonymous reviewer. This research was supported by NSF grant OCE0136835 to J.W.M. and S.D. R.W.J. was supported by an EPA STAR Fellowship.

\section{References}

Ammerman, J. W., R. R. Hood, D. A. Case, and J. B. Cotner (2003), Phosphorus deficiency in the Atlantic: An emerging paradigm in oceanography, Eos Trans. $A G U, 84(18)$, doi:10.1029/2003EO180001.

Archer, D., and E. Maier-Reimer (1994), Effect of deep-sea sedimentary calcite preservation on atmospheric $\mathrm{CO}_{2}$ concentration, Nature, 367, $260-263$.

Arimoto, R., R. A. Duce, B. J. Ray, and U. Tomza (2003), Dry deposition of trace elements to the western North Atlantic, Global Biogeochem. Cycles, 17(1), 1010, doi:10.1029/2001GB001406.

Armstrong, F. A. J., P. M. Williams, and J. D. H. Strickland (1966), Photooxidation of organic matter in sea water by ultra-violet radiation, analytical and other applications, Nature, 211, 481-483.

Berman-Frank, I., J. T. Cullen, Y. Shaked, R. M. Sherrell, and P. G. Falkowski (2001), Iron availability, cellular iron quotas, and nitrogen fixation in Trichodesmium, Limnol. Oceanogr., 46, 1249-1260.

Brand, L. E., W. G. Sunda, and R. R. L. Guillard (1983), Limitation of marine phytoplankton reproductive rates by zinc, manganese, and iron, Limnol. Oceanogr., 28, 1182-1198.

Bruland, K. W., and R. P. Franks (1983), Mn, Ni, Cu, Zn and $\mathrm{Cd}$ in the western North Atlantic, in Trace Metals in Seawater, vol. 9, edited by C. Wong et al., NATO Conf. Ser. 4, pp. 395-414, Springer, New York.

Cavender-Bares, K. K., D. M. Karl, and S. W. Chisholm (2001), Nutrient gradients in the western North Atlantic Ocean: Relationship to microbial community structure and comparison to patterns in the Pacific Ocean, Deep Sea Res., Part I, 48, 2373-2395.

Cembella, A. D., N. J. Antia, and P. J. Harrison (1984), The utilization of inorganic and organic phosphorus compounds as nutrients by eukaryotic microalgae: A multidisciplinary perspective: part 1, CRC Crit. Rev. Microbiol., 10, 317-391.

Cotner, J. B., J. W. Ammerman, E. R. Peele, and E. Bentzen (1997), Phosphorus-limited bacterioplankton growth in the Sargasso Sea, Aquat. Microb. Ecol., 13, 141-149.

Duce, R. A., and N. W. Tindale (1991), Atmospheric transport of iron and its deposition in the ocean, Limnol. Oceanogr., 36, 1715-1726.

Dyhrman, S. T., and B. Palenik (2003), Characterization of ectoenzyme activity and phosphate-regulated proteins in the coccolithophorid Emiliania huxleyi, J. Plankton Res., 25, 1215-1225.

Dyhrman, S. T., and K. C. Ruttenberg (2006), Presence and regulation of alkaline phosphatase activity in eukaryotic phytoplankton from the coastal ocean: Implications for dissolved organic phosphorus remineralization, Limnol. Oceanogr., 51, 1381-1390.

Dyhrman, S. T., E. A. Webb, D. M. Anderson, J. W. Moffett, and J. B. Waterbury (2002), Cell-specific detection of phosphorus stress in Trichodesmium from the Western North Atlantic, Limnol. Oceanogr., 47, 1832-1836.

Dyhrman, S. T., P. D. Chappell, S. T. Haley, J. W. Moffett, E. D. Orchard, J. B Waterbury, and E. A. Webb (2006), Phosphonate utilization by the globally important marine diazotroph Trichodesmium, Nature, 439, 68-71.

Ellwood, M. J., and C. M. G. van den Berg (2000), Zinc speciation in the northeastern Atlantic Ocean, Mar. Chem., 68, 295-306.

Ellwood, M. J., and C. M. G. van den Berg (2001), Determination of organic complexation of cobalt in seawater by cathodic stripping voltammetry, Mar. Chem., 75, 33-47.

Gong, N., C. Chen, L. Xie, H. Chen, X. Lin, and R. Zhang (2005), Characterization of a thermostable alkaline phosphatase from a novel species Thermus yunnanensis sp. nov. and investigation of its cobalt activation at high temperature, Biochim. Biophys. Acta, 1750, 103-111. 
Graziano, L. M., R. J. Geider, W. K. W. Li, and M. Olaizola (1996), Nitrogen limitation of North Atlantic phytoplankton: Analysis of physiological condition in nutrient enrichment experiments, Aquat. Microb. Ecol., 11, 53-64.

Guillard, R. R. L. (1975), Culture of phytoplankton for feeding marine invertebrates, in Culture of Marine Invertebrate Animals, edited by W. L. Smith and M. H. Chanley, pp. 26-60, Springer, New York.

Guillard, R. R. L., and J. H. Ryther (1962), Studies of marine planktonic diatoms. part I: Cyclotella nana Hustedt and Detonula conferevacea (Cleve) Gran, Can. J. Microbiol., 8, 229-239.

Haidar, A. T., and H. R. Thierstein (2001), Coccolithophore dynamics off Bermuda (N. Atlantic), Deep Sea Res., Part II, 48, 1925-1956.

Henderson, G. M., et al. (2007), GEOTRACES - An international study of the global marine biogeochemical cycles of trace elements and their isotopes, Chem. Erde, 67, 85-131.

Herbland, A., A. L. Bouteiller, and P. Raimbault (1985), Size structure of phytoplankton biomass in the equatorial Atlantic Ocean, Deep Sea Res., $32,819-836$

Jakuba, R. W., J. W. Moffett, and M. A. Saito (2008), Use of a modified, highsensitivity, anodic stripping voltammetry method for determination of zinc speciation in the North Atlantic Ocean, Anal. Chim. Acta, 614, 143-152.

Johnson, D. L. (1971), Simultaneous determination of arsenate and phosphate in natural waters, Environ. Sci. Technol., 5, 411-414.

Karl, D. M., and G. Tien (1992), MAGIC: A sensitive and precise method for measuring dissolved phosphorus in aquatic environments, Limnol. Oceanogr., 37, 105-116.

Kolowith, L. C., E. D. Ingall, and R. Benner (2001), Composition and cycling of marine organic phosphorus, Limnol. Oceanogr., 46, 309-320

Kulakova, A. N., G. B. Wisdom, L. A. Kulakov, and J. P. Quinn (2003), The purification and characterization of phosphonopyruvate hydrolase, a novel carbon-phosphorus bond cleavage enzyme from Variovorax sp. Pal2, J. Biol. Chem., 278, 23,426-23,431.

Landry, D. M., T. Gaasterland, and B. P. Palenik (2006), Molecular characterization of a phosphate-regulated cell-surface protein from the coccolithophorid Emiliania huxleyi (Prymnesiophyceae), J. Phycol., 42, 814-821.

Lane, T. W., and F. M. M. Morel (2000), Regulation of carbonic anhydrase expression by zinc, cobalt, and carbon dioxide in the marine diatom Thalassiosira weissflogii, Plant Physiol., 123, 345-352.

Li, H., M. J. W. Veldhuis, and A. F. Post (1998), Alkaline phosphatase activities among planktonic communities in the northern Red Sea, Mar. Ecol., Prog. Ser., 173, 107-115.

Lomas, M. W., A. Swain, R. Shelton, and J. W. Ammerman (2004), Taxonomic variability of phosphorus stress in Sargasso Sea phytoplankton, Limnol. Oceanogr., 49, 2303-2310.

Lyman, J., and R. H. Fleming (1940), Composition of seawater, J. Mar. Res., 3, 134-146.

Martin, J. H., and R. M. Gordon (1988), Northeast Pacific iron distributions in relation to phytoplankton productivity, Deep Sea Res., Part A, 35, $177-196$.

Martin, J. H., R. M. Gordon, S. Fitzwater, and W. W. Broenkow (1989), VERTEX: Phytoplankton/iron studies in the Gulf of Alaska, Deep Sea Res., Part A, 36, 649-680.

Martin, J. H., S. E. Fitzwater, R. M. Gordon, C. N. Hunter, and S. J. Tanner (1993), Iron, primary production and carbon-nitrogen flux studies during the JGOFS North Atlantic Bloom Experiment, Deep Sea Res., Part II, 40, $115-134$.

Mather, R. L., et al. (2008), Phosphorus cycling in the North and South Atlantic Ocean subtropical gyres, Nat. Geosci., 1, 439-443.

Michaels, A. F., and A. H. Knap (1996), Overview of the U.S. JGOFS Bermuda Atlantic Time-Series Study and the Hydrostation S Program, Deep Sea Res., Part II, 43, 157-198.

Mills, M. M., C. Ridame, M. Davey, J. L. Roche, and R. J. Geider (2004), Iron and phosphorus co-limit nitrogen fixation in the eastern tropical North Atlantic, Nature, 429, 292-294

Moffett, J. W., and J. Ho (1996), Oxidation of cobalt and manganese in seawater via a common microbially catalyzed pathway, Geochim. Cosmochim. Acta, 60, 3415-3424

Moore, C. M., M. M. Mills, R. Langlois, A. Milne, E. P. Achterberg, J. La Roche, and R. J. Geider (2008), Relative influence of nitrogen and phosphorus availability on phytoplankton physiology and productivity in the oligotrophic sub-tropical North Atlantic Ocean, Limnol. Oceanogr., 53, $291-305$

Murphy, J., and J. P. Riley (1962), A modified single solution method for the determination of phosphate in natural waters, Anal. Chim. Acta, 27, 31-36.

Perry, M. A. (1972), Alkaline phosphatase activity in subtropical Central North Pacific waters using a sensitive fluorometric method, Mar. Biol., $15,113-119$.
Plocke, D. J., C. Levinthal, and B. L. Vallee (1962), Alkaline phosphatase of Escherichia coli: A zinc metalloenzyme, Biochemistry, 1, 373-378.

Rimmelin, P., and T. Moutin (2005), Re-examination of the MAGIC method to determine low orthophosphate concentration in seawater, Anal. Chim. Acta, 548, 174-182.

Ruttenberg, K. C., and S. T. Dyhrman (2005), Temporal and spatial variability of dissolved organic and inorganic phosphorus, and metrics of phosphorus bioavailability in an upwelling-dominated coastal system, J. Geophys. Res., 110, C10S13, doi:10.1029/2004JC002837.

Saito, M. A., and J. W. Moffett (2001), Complexation of cobalt by natural organic ligands in the Sargasso Sea as determined by a new high-sensitivity electrochemical cobalt speciation method suitable for open ocean work, Mar. Chem., 75, 49-68.

Saito, M. A., and J. W. Moffett (2002), Temporal and spatial variability of cobalt in the Atlantic Ocean, Geochim. Cosmochim. Acta, 66, 1943-1953.

Saito, M. A., and D. L. Schneider (2006), Examination of precipitation chemistry and improvements in precision using the $\mathrm{Mg}(\mathrm{OH})_{2}$ preconcentration inductively coupled plasma mass spectrometry (ICP-MS) method for high-throughput analysis of open-ocean Fe and Mn in seawater, Anal. Chim. Acta, 565, 222-233.

Saito, M. A., D. M. Sigman, and F. M. M. Morel (2003), The bioinorganic chemistry of the ancient ocean: The co-evolution of cyanobacterial meta requirements and biogeochemical cycles at the Archean-Proterozoic boundary?, Inorg. Chim. Acta, 356, 308-318.

Saito, M. A., J. W. Moffett, S. W. Chisholm, and J. B. Waterbury (2002), Cobalt limitation and uptake in Prochlorococcus, Limnol. Oceanogr., 47, $1629-1636$

Sanudo-Wilhelmy, S. A., et al. (2001), Phosphorus limitation of nitrogen fixation by Trichodesmium in the central Atlantic Ocean, Nature, 411 $66-69$.

Shaked, Y., Y. Xu, K. Leblanc, and F. M. M. Morel (2006), Zinc availability and alkaline phosphatase activity in Emiliania huxleyi: Implications for Zn-P co-limitation in the ocean, Limnol. Oceanogr., 51, 299-309.

Sherrell, R. M., and E. A. Boyle (1992), The trace metal composition of suspended particles in the oceanic water column near Bermuda, Earth Planet. Sci. Lett., 111, 155-174.

Siegel, D. A., R. Iturriaga, R. R. Bidigare, R. C. Smith, H. Pak, T. D. Dickey, J. Marra, and K. S. Baker (1990), Meridional variations of the springtime phytoplankton community in the Sargasso Sea, J. Mar. Res., $48,379-412$.

Sunda, W. G., and S. A. Huntsman (1995), Cobalt and zinc interreplacement in marine phytoplankton: Biological and geochemical implications, Limnol Oceanogr, 40, 1404-1417.

Sunda, W. G., and S. A. Huntsman (2000), Effect of Zn, Mn, and Fe on Cd accumulation in phytoplankton: Implications for oceanic $\mathrm{Cd}$ cycling, Limnol. Oceanogr. 45, 1501-1516.

Taylor, S. R., and S. M. McLennan (1985), The Continental Crust: Its Composition and Evolution, Blackwell Sci., Malden, Mass.

Vidal, M., C. M. Duarte, S. Agusti, J. M. Gasol, and D. Vaque (2003), Alkaline phosphatase activities in the central Atlantic Ocean indicate large areas with phosphorus deficiency, Mar. Ecol., Prog. Ser., 262, 43-53.

Wu, J., and E. A. Boyle (1998), Determination of iron in seawater by highresolution isotope dilution inductively couple plasma mass spectrometry after $\mathrm{Mg}(\mathrm{OH})_{2}$ coprecipitation, Anal. Chim. Acta, 367, 183-191.

Wu, J., W. Sunda, E. A. Boyle, and D. M. Karl (2000), Phosphate depletion in the western North Atlantic Ocean, Science, 289, 759-762.

Xu, Y., D. Tang, Y. Shaked, and F. M. M. Morel (2007), Zinc, cadmium, and cobalt interreplacement and relative use efficiencies in the coccolithophore Emiliania huxleyi, Limnol. Oceanogr., 52, 2294-2305.

Xu, Y., T. M. Wahlund, L. Feng, Y. Shaked, and F. M. M. Morel (2006), A novel alkaline phosphatase in the coccolithophore Emiliania huxleyi (Prymnesiophyceae) and its regulation by phosphorus, J. Phycol., 42, $835-844$.

S. T. Dyhrman, Biology Department, Woods Hole Oceanographic Institution, WHOI MS \#33, Woods Hole, MA 02543, USA.

R. W. Jakuba, Office of Research and Development, Environmental Protection Agency, 1200 Pennsylvania Avenue, Northwest, Washington, DC 20460-0001, USA. (rachel.jakuba@gmail.com)

J. W. Moffett, Department of Biological Sciences, University of Southern California, AHF 205, MC 0371, Los Angeles, CA 90089-0371, USA. 